\title{
Molecular phylogeny of bladderworts: A wide approach of Utricularia (Lentibulariaceae) species relationships based on six plastidial and nuclear DNA sequences
}

\author{
Saura R. Silva ${ }^{\mathrm{a}, \mathrm{b}}$, Robert Gibson ${ }^{\mathrm{c}}$, Lubomír Adamec ${ }^{\mathrm{d}}$, Yoannis Domínguez ${ }^{\mathrm{e}}$, Vitor F.O. Miranda ${ }^{\mathrm{b}, \mathrm{a}, *}$ \\ ${ }^{a}$ Universidade Estadual Paulista (Unesp), Instituto de Biociências, Botucatu, São Paulo, Brazil \\ b Universidade Estadual Paulista (Unesp), Faculdade de Ciências Agrárias e Veterinárias, Jaboticabal, Departamento de Biologia Aplicada à Agropecuária, São Paulo, \\ Brazil. \\ c Office of Environment and Heritage, Department of Premier and Cabinet, Newcastle, NSW, Australia \\ d Institute of Botany of the Czech Academy of Sciences, Třebon̆, Czech Republic \\ e Universidade Estadual Paulista (Unesp), Instituto de Biociências, São Vicente, São Paulo, Brazil
}

\section{A R T I C L E I N F O}

\section{Keywords:}

Utricularia

Bladderwort

Carnivorous plant

DNA sequencing

Multilocus phylogeny

\begin{abstract}
A B S T R A C T
The carnivorous plant genus Utricularia L. (bladderwort) comprises about 240 species distributed worldwide and is traditionally classified into two subgenera (Polypompholyx and Utricularia) and 35 sections, based mainly on general and trap morphology. It is one out of the largest carnivorous genera, representing ca. $30 \%$ of all carnivorous plant species, and is also the most widely distributed. According to previous phylogenetic studies, most infrageneric sections are monophyletic, but there are several incongruences considering their relationships and also the dissenting position of some species as a result of a too few (mostly one or two) molecular markers analyzed. Thus, here we present a multilocus phylogeny for Utricularia species with a wide taxonomic sampling (78 species and 115 accessions) based on six plastid ( rbcL, matK, rpl20-rps12, rps16, trnL-F) and nuclear DNA (ITS region) sequences. The aim is to reconstruct a well-resolved tree to propose evolutionary and biogeographic hypotheses for the radiation of lineages with inferences about the divergence times of clades using a molecular clock approach.
\end{abstract}

\section{Introduction}

The family Lentibulariaceae comprises three genera: Utricularia L., Genlisea A.St.-Hil. and Pinguicula L.; all of which are carnivorous herbs. The genus Utricularia comprises plants known as bladderworts and holds about 240 species traditionally classified in two subgenera and 35 sections since Taylor's monograph (1989; Fleischmann, 2015; Rutishauser, 2016). It is one out of the largest carnivorous plant genera and is also the most widely distributed, representing ca. $30 \%$ of all carnivorous plants taxa (Król et al., 2012). Bladderworts are one of the most intriguing carnivorous plants, with traps of such structural and physiological complexity that they are still not fully understood (Juniper et al., 1989; Rutishauser and Isler, 2001; Poppinga et al., 2015). The traps, known as utricles, are leaf-like structures shaped in small vesicles, which are active in prey capture and secretion of hydrolytic enzymes for digesting small animals (Adamec et al., 2010; Król et al., 2012; Lloyd, 1935; Poppinga et al., 2015; Sirová et al., 2003,
2009).

All Utricularia species are herbs and their vegetative structures do not follow traditional models of morphological classification. The archetypes of body organization of Utricularia do not present clearly defined boundaries between typical plant organs (e.g. stems, leaves) and these plants do not have roots (Rutishauser and Isler, 2001). Bladderworts are adapted to colonize different environments, from land with terrestrial, lithophyte and epiphyte species to open water with freefloating and affixed aquatic species, rheophytes, and epiphytes (Taylor, 1989).

The taxonomic system proposed by Taylor (1989), still the most important taxonomic reference to the genus, is based mainly on morphological characters; especially reproductive structures (calyx, corolla, peduncle and seed) and traps. Utricularia shows a great phenotypic plasticity, both intra and inter-specific, and hence species are often taxonomically difficult to identify.

Bladderworts have attracted special interest by many researchers

* Corresponding author at: Universidade Estadual Paulista (Unesp), Faculdade de Ciências Agrárias e Veterinárias, Jaboticabal, Departamento de Biologia Aplicada à Agropecuária, São Paulo, Brazil.

E-mail addresses: saura.silva@gmail.com (S.R. Silva), robert.gibson@environment.nsw.gov.au (R. Gibson), lubomir.adamec@ibot.cas.cz (L. Adamec), yoannisd@gmail.com (Y. Domínguez), vmiranda@fcav.unesp.br (V.F.O. Miranda). 
since the recent discovery that both Utricularia and Genlisea have species with the smallest genomes currently known within the angiosperms (Ibarra-Laclette et al., 2013). The chromosomes sizes of some species are comparable to the size of bacteria (Fleischmann et al., 2014; Greilhuber et al., 2006) and there is a wide variation in genome size within genera and species (Veleba et al., 2014). Also, high rates of mutation among all intracellular compartments have also been reported (Jobson and Albert, 2002; Müller and Borsch, 2005). Therefore, Utricularia and Genlisea species can be extraordinarily suitable model plants for understanding the process of miniaturization of genomes (Albert et al., 2010; Fleischmann et al. 2014; Greilhuber et al. 2006; IbarraLaclette et al., 2011, 2013). This primarily applies to the range of genome sizes found within both genera. It is remarkable that ultra-small genomes $(1 \mathrm{C}<100 \mathrm{Mbp})$ have evolved independently in at least three independent lineages in the genus Utricularia (Veleba et al., 2014).

According to previous phylogenetic studies, in general, most sections proposed by Taylor (1989) are monophyletic. Nevertheless, there are several incongruences between the clades, considering their relationships and also the dissenting position of some species. In attempt to solve these issues, Müller et al. (2006) used the supertrees approach, however important questions still remained unsolved, such as the phylogenetic interrelationship of Utricularia subgenera Polypompholyx and Utricularia, which is still ambiguous. Thus the need of a broad phylogenetic analysis is evident, mainly of Utricularia species. The previously published studies focused only on a few markers, and then they were primarily partial sequences from cpDNA such as matK, rps16, trnL-F and trnK (Jobson and Albert, 2002; Jobson et al., 2003; Müller and Borsch, 2005; Reut and Jobson, 2010; Westermeier et al., 2017). Therefore, a robust phylogenetic analysis of Utricularia species is clearly needed, with a premise that a wide taxonomic sampling with several DNA markers could untangle the evolutionary relationships of bladderworts.

Here we evaluate a multilocus phylogeny for Utricularia species with no precedents, including both the wide taxonomical representation (78 species and 115 accessions of Utricularia) and also the DNA markers sampled (five from plastid and one region from the nuclear genome). We aimed to: (1) reconstruct a well-resolved tree based on five chloroplast sequences from the plastid genome ( $r b c L$, matK, rpl20-rps12, rps16, trnL-trnF) and one from the nuclear genome (ITS rDNA: ITS1 + 5.8S + ITS2); (2) propose an evolutionary hypothesis for the radiation of lineages and species in different habitats; (3) propose a biogeographical hypothesis for the Utricularia lineages; and, (4) infer the divergence time of clades using a molecular clock approach.

\section{Materials and methods}

\subsection{Plant material}

This study comprises 115 accessions representing 78 Utricularia species, resulting from leaves and flowers stored in silica gel samples collected from natural populations (mainly from Brazil and Australia), from cultivated specimens in Unesp/FCAV Jaboticabal, Brazil, and in the Aquatic and Wetland Plant Collection from the Institute of Botany, Třeboň, Czech Republic, and available sequences from GenBank (www. ncbi.nlm.gov; Table 1). The sectional classification of the genus Utricularia was followed as proposed by Taylor (1989). Genlisea and Pinguicula species were selected as the outgroup. Vouchers were deposited for all materials collected for this study in Herbarium JABU (Unesp/ FCAV campus Jaboticabal, Brazil) and the National Herbarium of New South Wales (NSW).

\subsection{Life forms and geographic distribution of taxa}

The data about the life forms of all taxa was adopted from Taylor (1989) and also our own observations of the species in nature. Therefore, to simplify the analysis and trace possible ancestral forms, we have adapted the life form categories from Taylor's classification (1989), making no distinction between the different aquatic habits (e.g., freefloating and affixed aquatic species were considered as aquatic) and also considering lithophyte as terrestrial species. Thus, we considered only four life forms: aquatic, epiphyte, rheophyte and terrestrial. The geographic distribution of each species was also based on Taylor (1989).

\subsection{DNA extraction and polymerase chain reaction (PCR)}

We performed the DNA extractions according to the Doyle and Doyle (1987) protocol with modifications by Lodhi et al. (1994) for fresh plant tissue and dehydrated samples from silica gel preserved specimens. The amplified chloroplast regions were $r b c L$ (using primers $r b c L a-\mathrm{F}, r b c L a-\mathrm{R}$; Kress et al., 2009; Levin et al., 2003), matK (3F- KIM and 1RKIM; Li et al., 2011), the intergenic spacer rpl20-rps12 (5'-rps12 and rpl20; Hamilton, 1999) and the ITS region (ITS4 and ITS5; White et al., 1990) from the rDNA.

PCRs were achieved using Taq DNA polymerase (Thermo Scientific Fermentas $^{\circledast}$, Pittsburgh, PA, USA) containing $20 \mathrm{mM} \mathrm{MgCl}_{2}$, nucleotides, buffer, including reactions with the adjuvant dimethyl sulfoxide (DMSO) when necessary, as recommended by Miranda et al. (2010) (for PCR and primers specifications see Table 2).

\subsection{DNA sequencing and alignment}

DNA sequencing was performed using Applied Biosystems ABI 3100. All chromatograms obtained from the sequences were analyzed for possible sequencing errors using the program BioEdit version 7.0.9.0 (Hall, 1999). Both forward and reverse frames were used for each sample for the construction of a consensus sequence. Several species were sequenced with bioreplicates; mostly specimens from distinct populations (see Table 1).

The sequence alignments were performed using MAFFT version 7 (Katoh and Standley, 2013) with the application of default parameters (FFT-NS-1, FFT-NS-2, FFT-NS-i or L-INS-i) and GAPs with default penalties. For the ITS matrix, due to sequences with low overlap to other alignments (with some distance pairwise values below 40\%), the software MaxAlign Server 1.1 (Gouveia-Oliveira et al., 2007) was employed to identify and remove sequences that caused too much disruption in the alignment by excess of saturation. Indels were treated as missing data.

2.5. Phylogenetic analyses - maximum parsimony, maximum likelihood, and Bayesian approach

Previous phylogenetic work on the Lentibulariaceae placed the clade Utricularia-Genlisea with Pinguicula as the sister group (Jobson and Albert, 2002; Müller et al., 2004). Therefore, species of Genlisea and Pinguicula were used as outgroup (Table 1) for this study. Maximum parsimony analyses (MP) were performed with PAUP* version $4 \mathrm{~b} 10$ software (Swofford, 2002). The most parsimonious trees were found by heuristic searches with random addition of sequences and 2000 replicates using the branch swapping algorithm Nearest Neighbor Interchange (NNI; Robinson, 1971). Clade support was assessed using bootstrap analysis (Felsenstein, 1985) with 2000 pseudoreplicates and heuristic search with 1000 replicates (with random addition of sequences with the branch swapping algorithm NNI). For probabilistic analyses, the best evolutionary models (best-of-fit) were searched for using jModelTest software version 2.1.1 (Santorum et al., 2014). Thus, the best-of-fit DNA model was evaluated for each data matrix with the corrected Akaike information criterion (AICc, Akaike, 1973; Burnham and Anderson, 2002) to estimate the parameters. The algorithm Metropolis-coupled Markov chain Monte Carlo (MCMCMC; Geyer, 1991); maximum likelihood (ML), and Bayesian analyses were performed to estimate the phylogenetic hypothesis for each data matrix. The ML 


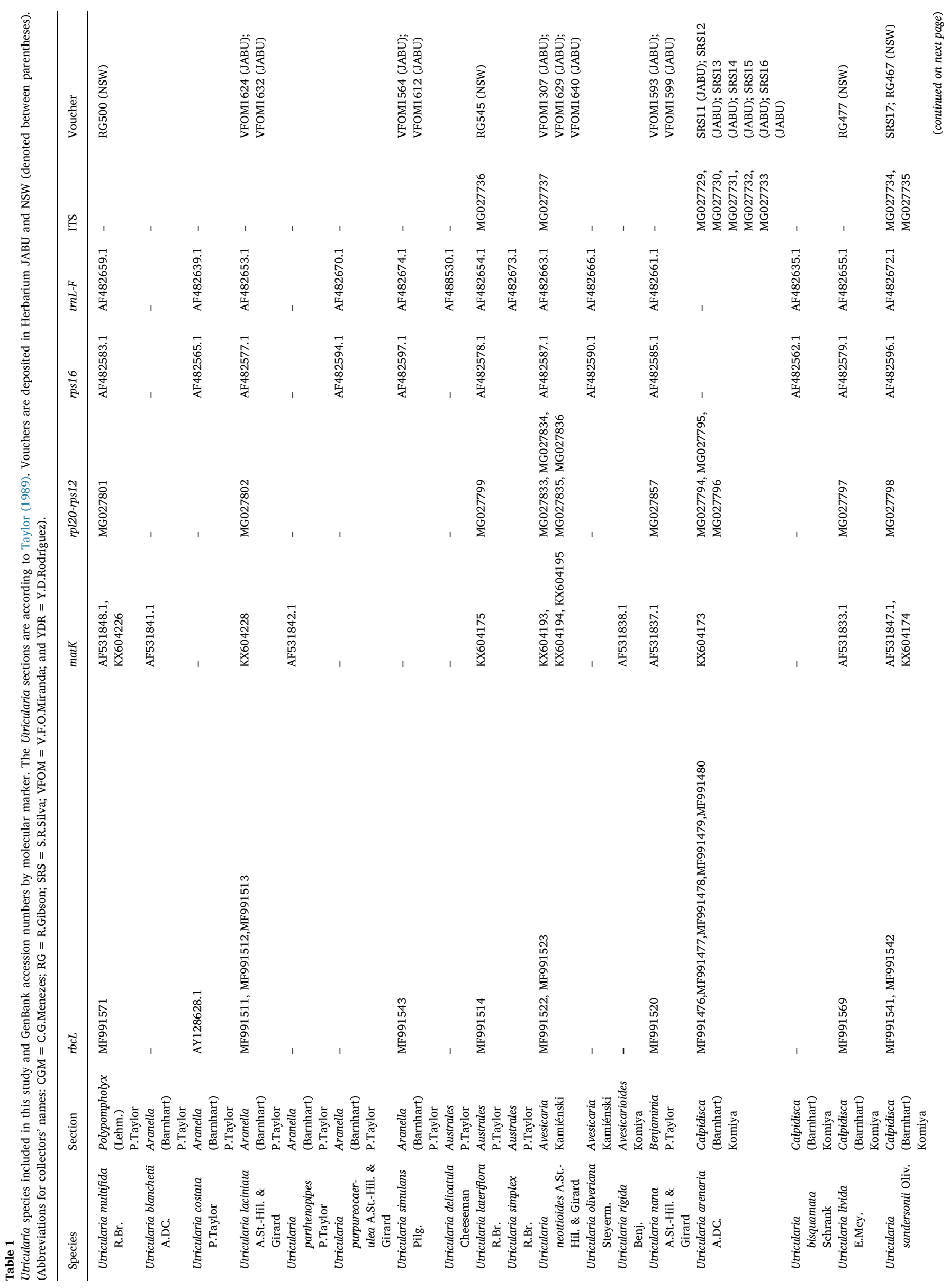




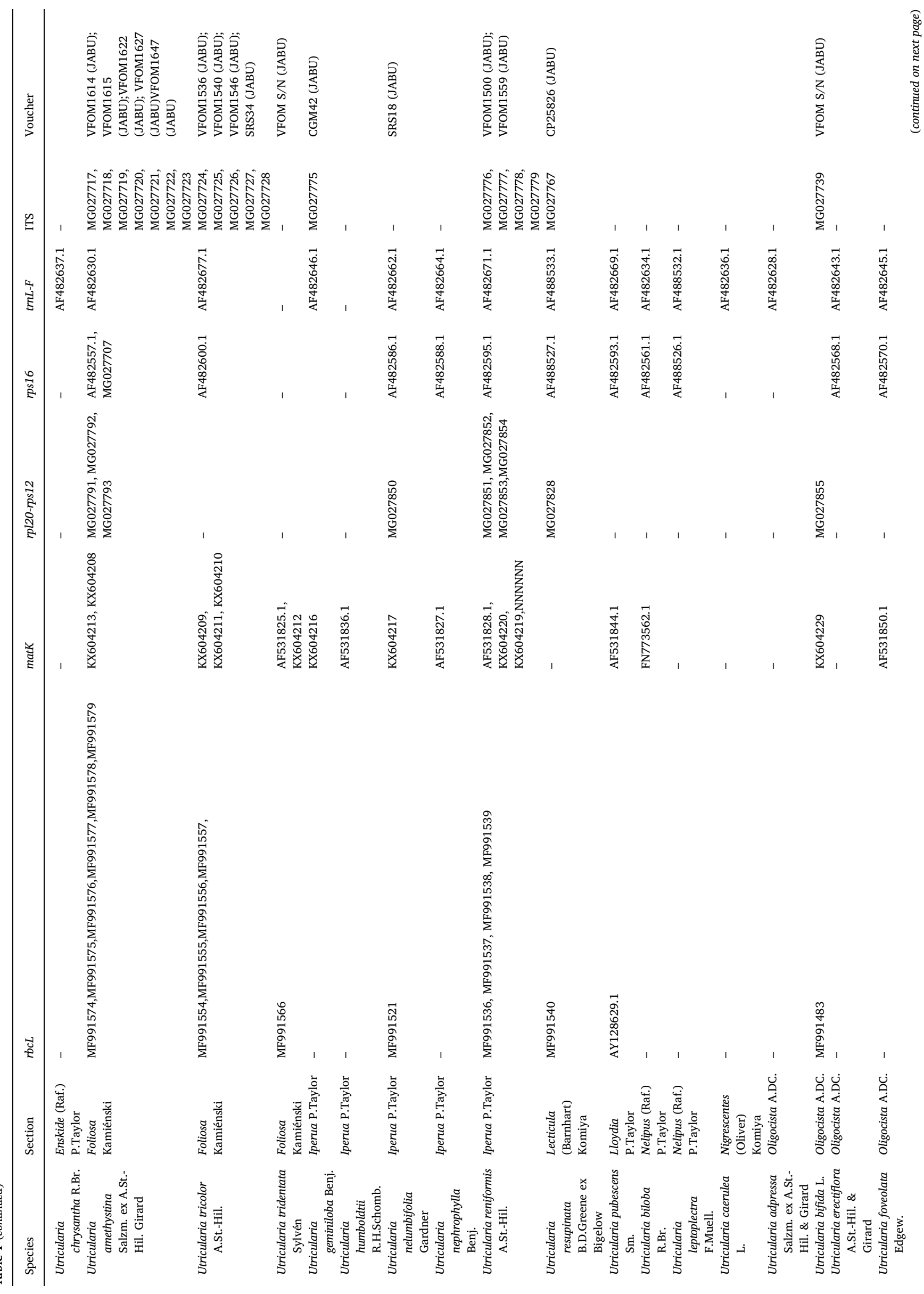




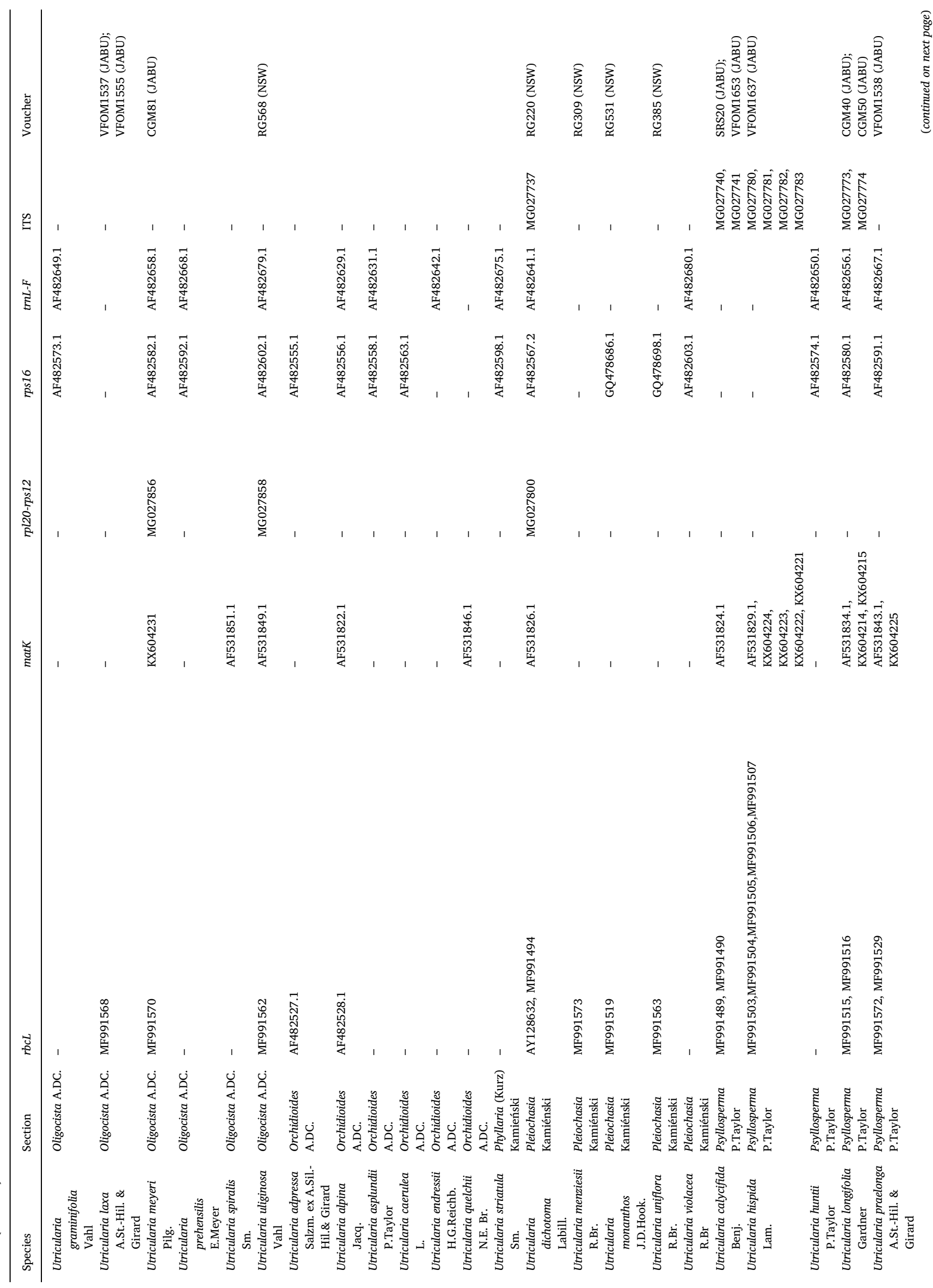




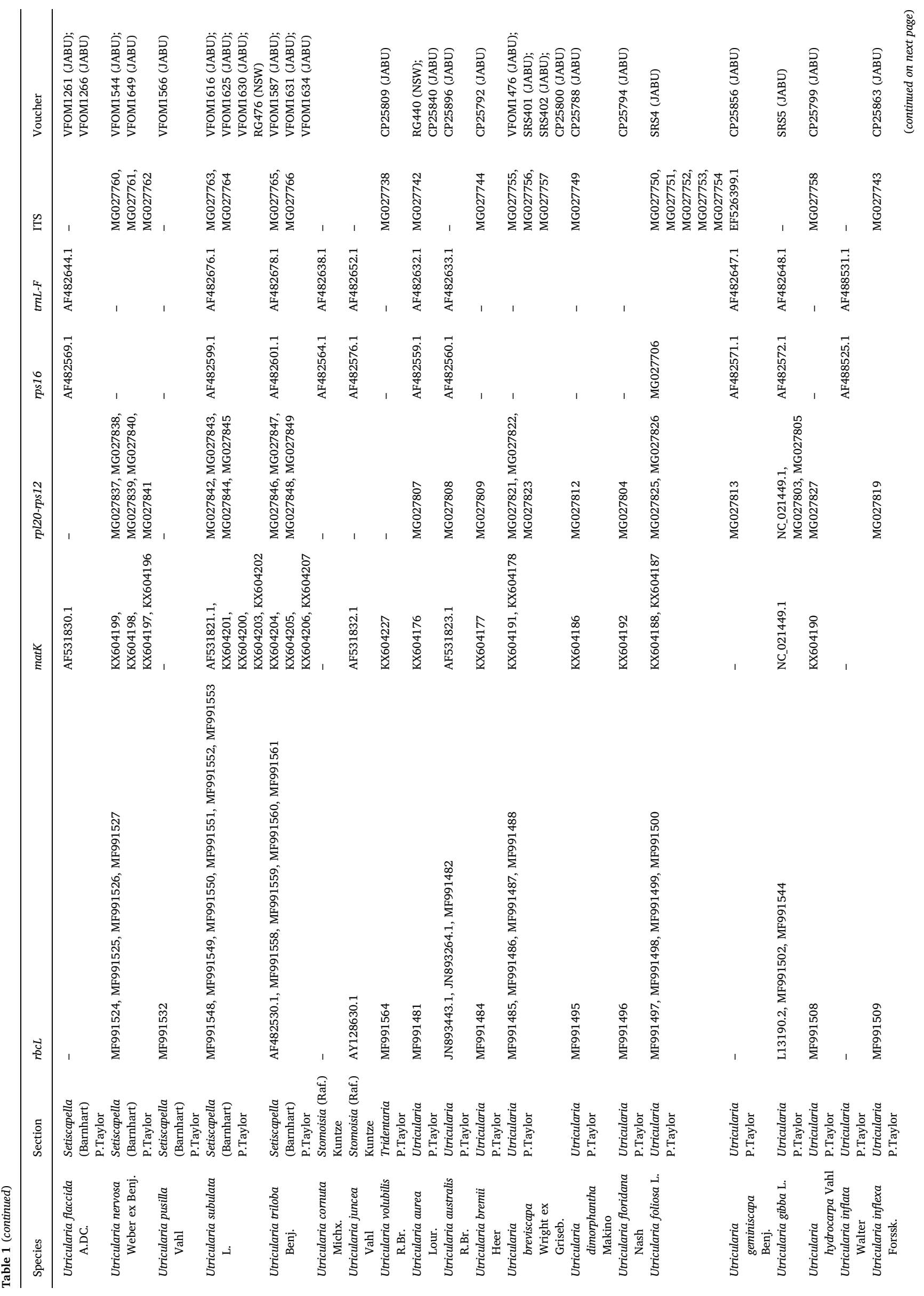




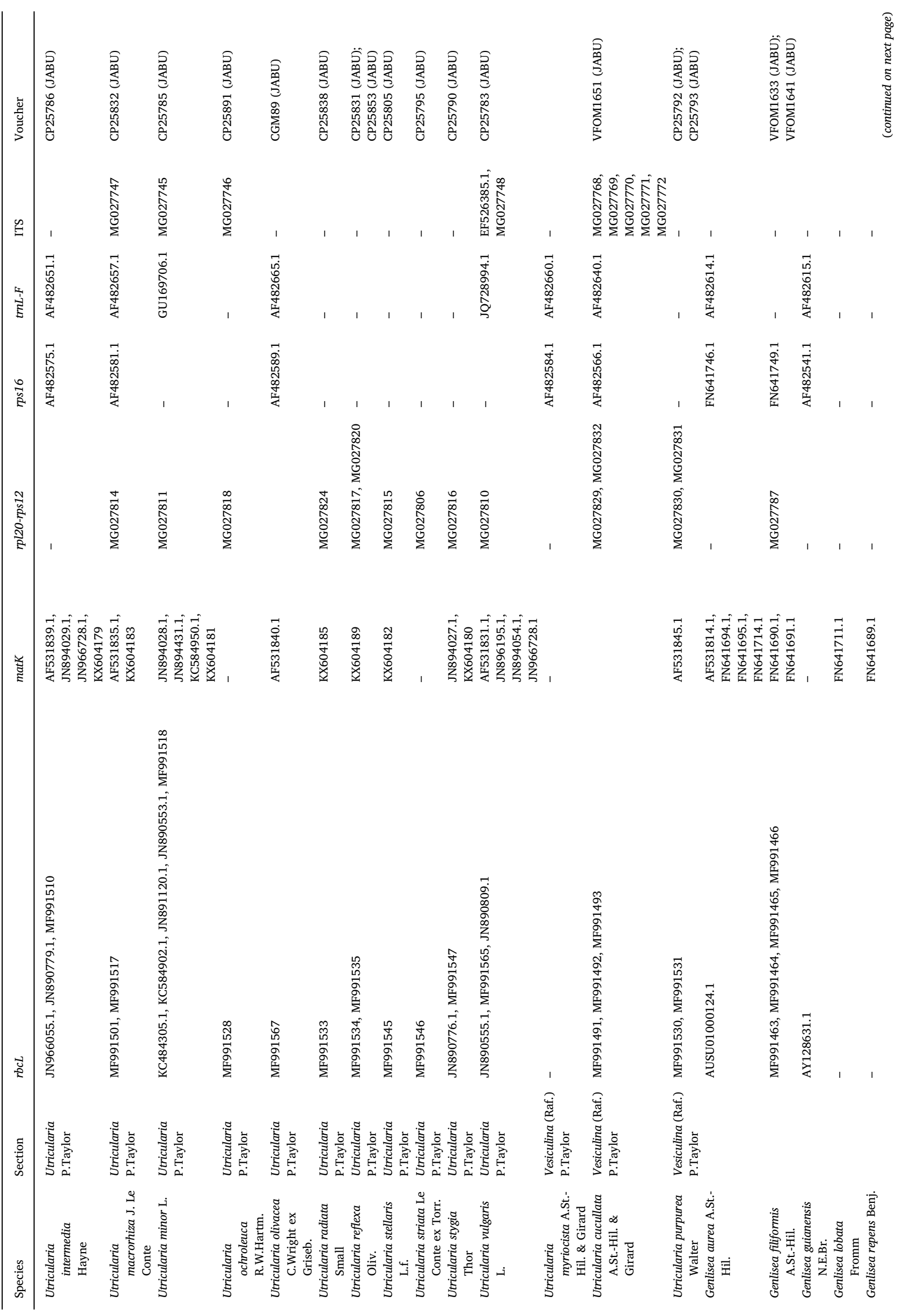




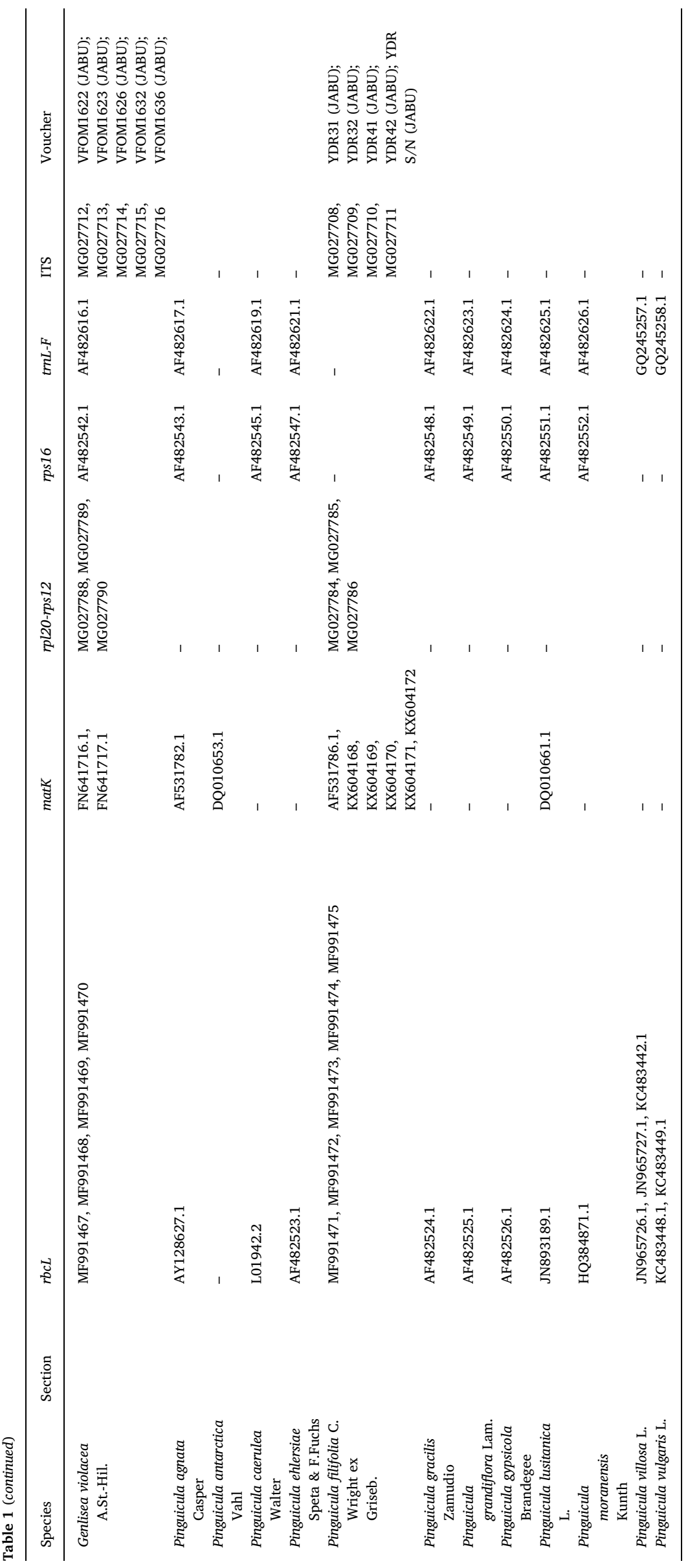


Table 2

Primers and PCR conditions of target sequences.

\begin{tabular}{|c|c|c|c|c|c|}
\hline Sequence & Primer name & Primer sequence $\left(5^{\prime}-3^{\prime}\right)$ & $\operatorname{AT}^{\mathrm{a}}\left({ }^{\circ} \mathrm{C}\right)$ & Extension time (s) & Reference to primers and amplification conditions \\
\hline \multirow[t]{2}{*}{$r b c L$} & rbcLa_f & ATGTCACCACAAACAGAGACTAAAGC & 50 & 60 & Levin (2013); this study \\
\hline & rbcLa_rev & GTAAAATCAAGTCCACCRCG & 50 & 60 & Kress et al. (2009); this study \\
\hline \multirow[t]{2}{*}{ matK } & 3F_KIM & CGTACAGTACTTTTGTGTTTACGAG & 52 & 20 & Li et al. (2011); this study \\
\hline & 1R_KIM & ACCCAGTCCATCTGGAAATCTTGGTTC & 52 & 20 & Li et al. (2011); this study \\
\hline \multirow[t]{2}{*}{ rpl20-rps12 } & rpl20 & TTTGTTCTACGTCTCCGAGC & 50 & 60 & Hamilton (1999); this study \\
\hline & 5'-rps12 & GTCGAGGAACATGTACTAGG & 50 & 60 & Hamilton (1999); this study \\
\hline \multirow[t]{2}{*}{ ITS } & ITS4 & TCCTTCCGCTTATTGATATGC & 50 & 50 & White et al. (1990), Miranda et al. (2010); this study \\
\hline & ITS5 & GGAAGTAAAAGTCGTAACAAGG & 50 & 50 & White et al. (1990), Miranda et al. (2010); this study \\
\hline
\end{tabular}

${ }^{\text {a }}$ Annealing temperature.

analyses were run using RAxML BlackBox program (Stamatakis et al., 2008). MCMCMC analyses were performed using MrBayes software version 3.2.2 (Huelsenbeck and Ronquist, 2001; Ronquist et al., 2012) for each data set with $9 \times 10^{6}$ generations sampled for each 100 generations, using the default parameters of the application. For each analysis two runs (nruns $=2$ ) with four chains (nchains $=4$ ) were performed beginning with random trees. Initial samples were discarded after reaching stationarity (estimated at $25 \%$ of the trees). The posterior probabilities (PP) for each clade were obtained by comparing and matching individual analyses with the analysis of a majority ( $>50 \%$ ) consensus tree. The analyses with RAxML and MrBayes applications were performed on the CIPRES resource (Miller et al., 2010). Cladograms (except the one with optimizations of ancestral states) were drawn with TreeGraph2 beta version 2.0.52-347 (Stöver and Müller, 2010) software. Further, cladograms included geographical data, the life forms of the species, and the inference of ancestral states using the software Mesquite version 2.75 (Maddison and Maddison, 2010).

\subsection{Molecular clock approach}

For molecular clock estimations, we used the $r b c L$ dataset because out of all the sequences in this study, only $r b c L$ was available for Pinguicula filifolia and this species was used as clock calibration point. We used the BEAST package v.1.8 (Drummond et al., 2012), with Markov chain Monte Carlo (MCMC) run for $10^{6}$ generations, sampling for each 100 generations. The first $10 \%$ of trees were discarded as burnin, and the remaining trees were combined in a maximum clade credibility tree using TreeAnnotator v. 1.6 (BEAST package). We used two calibration points: (i) the first was pollen grain fossils dated for Utricularia minor (11.6-23.0 mya; Muller, 1984) and (ii) the second was based on the insular separation of the western part of Cuba (Pinar del Río province) and Isla de la Juventud (1.8-5.3 mya; Ferrera et al., $1990)$ as their geological histories are very well studied. The molecular model HKY $+\Gamma$ was applied for the analysis, as it was found to be the best-of-fit model using jModelTest software version 2.1.1 (Santorum et al., 2014). The priors for the analyses (other than default) were: relaxed uncorrelated lognormal clock (estimated); Yule process of speciation; and a random starting tree. To this analysis, we included a $r b c L$ partial paleosequence (137 bp) found in the rumen of a Holocene Yakutian bison (Bison priscus) that was radiocarbon dated to about $10,500 \mathrm{cal}$ a BP (Van Geel et al., 2014). This estimate was not applied for molecular clock calibration as the bison age is too recent.

\subsection{Ancestral range reconstruction}

We used S-DIVA, implemented as options within RASP software (Yu et al., 2015) to reconstruct the possible ancestral ranges of Utricularia species on the phylogenetic tree, based on concatenated sequences (total evidence) generated with Bayesian inference. For that, the areas of occurrence were set as nine regions according to Taylor (1989): (A) North America; (B) Central America; (C) South America; (D) Europe and North Africa; (E) North Asia; (F) Africa; (G) Tropical Asia; (H) Malaysia; and (I) Australia, New Caledonia, and New Zealand. For SDIVA analysis the maximum areas was kept as four.

\section{Results}

\subsection{Analyses of individual and combined datasets, congruence and phylogenetic relationships of infrageneric taxa}

The six markers resulted in alignments of between $608(r b c L)$ and 1257 (trnL-trnF) sites, and the combined dataset (all the six markers concatenated) resulted in 6226 sites (Table 3). Since the preliminary alignments of ITS sequences resulted in some sequences with less than $60 \%$ pairwise similarity, we chose to exclude the dissimilar sequences to minimize the noise. Thus, with the aim to identify misaligned sequences caused by saturation and with lower level of identity (pairwise similarity $<65 \%$ ), we applied the MaxAlign (Gouveia-Oliveira et al.,

Table 3

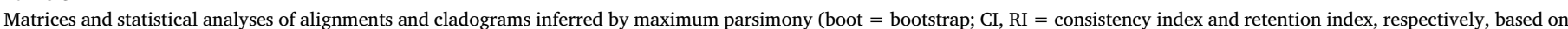
maximum parsimonious trees; $\mathrm{ML}=$ maximum likelihood; $\mathrm{MP}=$ maximum parsimony; MPT = most parsimonious trees; PP $=$ posterior probabilities based on Bayesian approach).

\begin{tabular}{|c|c|c|c|c|c|c|c|c|c|c|}
\hline \multirow[t]{2}{*}{ Matrix } & \multirow[t]{2}{*}{ Genome } & \multirow[t]{2}{*}{ Terminals $(n)$} & \multirow[t]{2}{*}{$\begin{array}{l}\text { Sites considering gaps } \\
\text { (bp) }\end{array}$} & \multirow[t]{2}{*}{$\begin{array}{l}\text { Variable sites (pb } \\
(\%))\end{array}$} & \multirow[t]{2}{*}{$\begin{array}{l}\text { Parsimonious informative } \\
\text { sites (pb) }\end{array}$} & \multicolumn{3}{|c|}{$\begin{array}{l}\text { Clades with support } \geq 50 \% \text { (n } \\
(\%))^{\mathrm{a}}\end{array}$} & \multirow[t]{2}{*}{$\mathrm{CI}$} & \multirow[t]{2}{*}{ RI } \\
\hline & & & & & & Boot MP & Boot ML & PP & & \\
\hline$r b c L$ & Chloroplast & 153 & 608 & $128(21)$ & 101 & $40(26)$ & $46(30)$ & $54(36)$ & 0.53 & 0.92 \\
\hline matK & Chloroplast & 119 & 960 & $582(61)$ & 471 & $63(53)$ & 70 (59) & $72(61)$ & 0.57 & 0.89 \\
\hline rpl20-rps12 & Chloroplast & 79 & 1096 & $498(45)$ & 345 & $35(45)$ & $45(58)$ & $50(64)$ & 0.65 & 0.90 \\
\hline rps16 & Chloroplast & 68 & 1220 & $739(61)$ & 503 & $49(73)$ & $62(93)$ & $64(96)$ & 0.48 & 0.59 \\
\hline$t r n L-t r n F$ & Chloroplast & 73 & 1257 & $736(59)$ & 505 & $55(76)$ & $64(88)$ & $62(86)$ & 0.47 & 0.68 \\
\hline ITS & Nucleus & 78 & 1091 & $818(75)$ & 753 & $34(44)$ & $39(51)$ & $50(65)$ & 0.43 & 0.83 \\
\hline Combined $^{\mathrm{b}}$ & Chloroplast + Nucleus & 93 & 6226 & 3449 (55) & 2442 & $69(75)$ & $88(96)$ & $86(93)$ & 0.40 & 0.62 \\
\hline
\end{tabular}

\footnotetext{
a The percentage of clades (\%) was calculated from the total number of possible clades of the trees (=total OTUs-1).

${ }^{\mathrm{b}}$ Only one sequence per species was used. Only taxa with at least two markers were considered for the combined dataset.
} 
2007) to the ITS alignment. After running the analysis, 27 sequences were excluded from the original ITS dataset: Pinguicula crystallina (DQ438082.1), P. filifolia (AB212104.1). P. lusitanica (DQ222960.1), P. primuliflora (DQ222964.1), P. vulgaris (DQ438093.1), Genlisea hispidula (AB212112.1), G. lobata (AB212113.1), G. pallida (AB212114.1), G. repens (AB212116.1), G. violacea (AB212116.1), Utricularia alpina (AB212117.1), U. bifida (KF016005.1), U. olivacea, $U$. furcellata (KF016006.1), U. intermedia (DQ225109.1), U. laxa, U. meyeri, U. minor (AB212118.1), $U$. multifida, $U$. nana, $U$. nelumbifolia, $U$. neottioides, $U$. purpurea, $U$. reflexa, U. reniformis (DQ225108.1), U. striata, and $U$. striatula (KF016004.1). After that, the ITS dataset (ITS1 + 5.8S + ITS2) comprised 1091 aligned nucleotides. The decision to exclude those 27 sequences decreased the proportion of variable sites, and this decision improved the robustness of the phylogenetic analyses by minimizing the homoplasy from the original dataset (data not shown).

Even after the exclusion of the sequences with low pairwise similarity, the ITS dataset contained a relatively high number of variable sites (75\%), followed by matK and rps16 from cpDNA (61\% each; Table 3). Despite the high level of substitutions found in ITS sequences, this dataset resulted in trees with an intermediate level of resolution, considering the proportion of clades with support of $50 \%$, or more, for the six markers used (Table 3; Fig. 3). The rps16 and trnL-trnF datasets resulted in the highest proportions of supported clades, unlike $r b c L$ that showed the lowest proportion of clades with high support, with $26 \%$ of clades supported by parsimony, 30\% supported by maximum likelihood, and $36 \%$ of clades supported by Bayesian posterior probabilities (with values of $50 \%$, or more). Nevertheless, the isolated rps16, trnL$t r n F$ and the ITS datasets resulted in the lowest consistency indices (CIs $=0.48,0.47$ and 0.43, respectively; Table 3). The $r b c L$, matK, and rpl20-rps12 datasets resulted in the highest retention indices (0.92, 0.89 , and 0.90 , respectively).

According to the phylogenetic hypotheses based on the combined datasets (Fig. 4) and on each isolated sequence (supplementary material), general topologies were congruent and supported most sections of the infrageneric classification of the genus Utricularia as proposed by Taylor (1989).

The combined tree also supports Utricularia subgen. Polypompholyx as the sister group of the clade comprising subgenera Utricularia + Bivalvaria (maximum parsimony bootstrap [MP], maximum likelihood bootstrap [ML], and posterior probability $[\mathrm{PP}]=1$; Fig. 4) and thus corroborating with previous studies (Jobson and Albert, 2002; Jobson et al., 2003). The individual datasets, matK, rps16, and trnL-trnF also support this topology. According to Bayesian estimates, $r b c L$ and ITS sequences do not resolve the relationship between the three subgenera resulting in a polytomy, and rpl20-rps12 places subgen. Polypompholyx nested within subgen. Bivalvaria (supplementary material).

\subsection{Evolution of life forms in Utricularia}

The ancestral life form of Utricularia is terrestrial, according to the isolated markers and also the combined dataset (Fig. 4) corroborating with what has been proposed by Müller and Borsch (2005) and Müller et al. (2006). This plesiomorphic condition is in agreement with the predominant life form of the sister genus Genlisea (Fischer et al., 2000; Fleischmann et al., 2011) and Pinguicula (Casper, 1966; Roccia et al., 2016). Most aquatic species are nested in Utricularia sect. Utricularia, and this life form arose at least four times in the genus Utricularia according to our hypothesis: (1) U. volubilis (sect. Pleiochasia; also, U. tubulata is an aquatic species of this section, but it was not included in this study), (2) U. foveolata and U. uliginosa (sect. Oligocista, assuming one synapomorphy with the reversion to $U$. graminifolia, or a synapomorphy to the $U$. foveolata- $U$. graminifolia- $U$. uliginosa clade, since this species can be considered aquatic according to Taylor, 1989), (3) $U$. nelumbifolia (sect. Iperua, an aquatic and epiphyte species found inside bromeliads phytotelmata), and (4) the clade comprising sect. Utricularia + sect. Vesiculina + sect. Avesicaria + sect. Setiscapella + sect. Nelipus. In this latter clade, it is necessary to assume the reversion to $U$. flaccida and species from sect. Setiscapella, and also the arisen rheophytic life form of sect. Avesicaria (U. neottioides and U. oliveriana). The ephiphytic form occurs as a synapomorphy in $U$. alpina and $U$. asplundii (or a synapomorphy to the group formed by the sections Iperua and Orchidioides, with possible reversions to the species with other life forms), and also of $U$. striatula; in the latter case as a possible synapomorphy to sect. Phyllaria since this section is formed mostly by lithophytes and also epiphytes.

\subsection{Biogeography and ancestral ranges reconstruction}

The molecular clock tree based on $r b c L$ sequences is shown in Fig. 7, and the divergence time estimates for the major lineages are depicted in Table 4. According to our estimates, the last common ancestor of Genlisea + Utricularia was possibly a South American lineage (Fig. 6) that arose 39 million years ago (mya). The genus Utricularia diverged around 30 mya and dispersed to Australia, with the lineage represented by the subgenus Polypompholyx, and possibly to Africa afterwards (Figs. 6-8).

\section{Discussion}

\subsection{Evolutionary and phylogenetic characteristics of different DNA sequences}

This study used both chloroplast and nuclear DNA, targeting sequences with distinct functions in the genome (rps16 intron, rpl20-
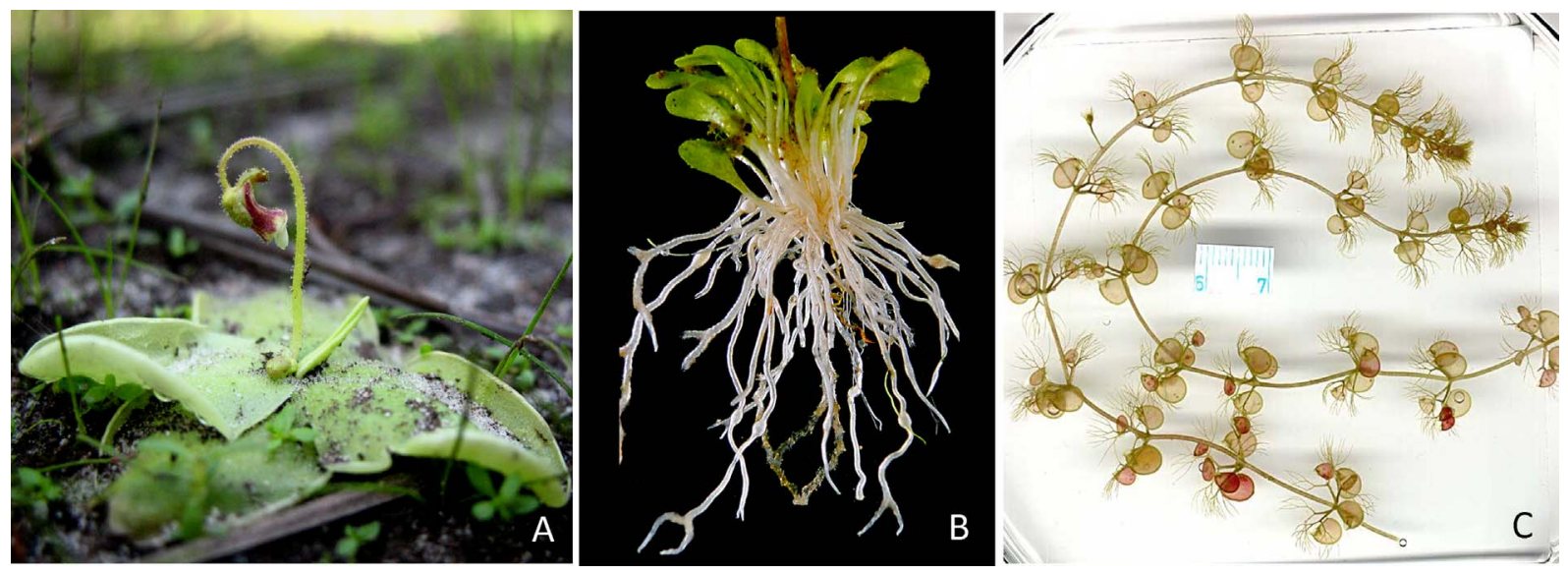

Fig. 1. Habit of the three genera: (A) Pinguicula, (B) Genlisea and (C) Utricularia. 

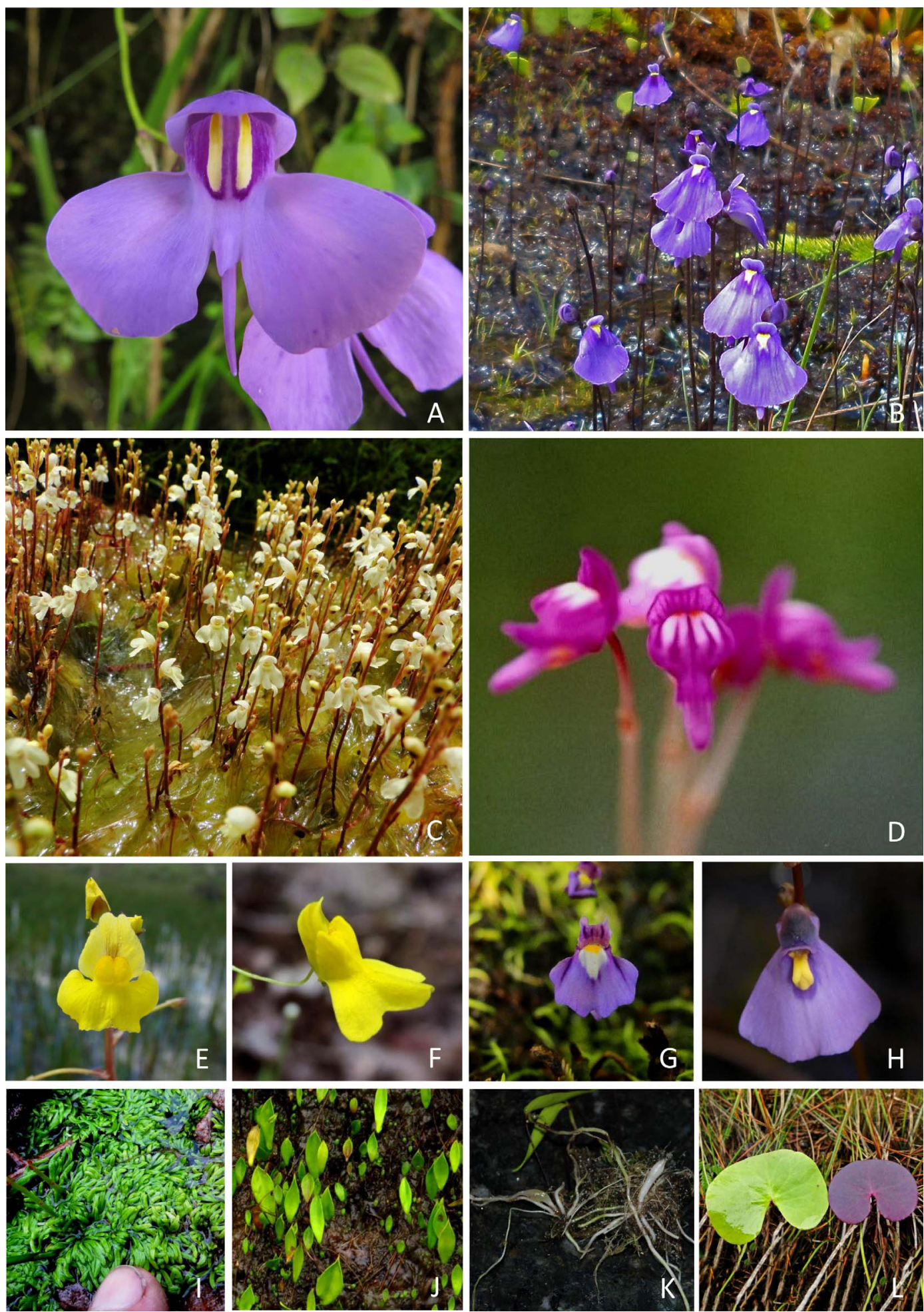

Fig. 2. Utricularia species: (A, L) U. reniformis A.St.-Hil.; (B) U. pubescens Sm.; (C) U. neottioides A.St.-Hil. \& Girard; (D) U. cucullata A.St.-Hil. \& Girard; (E) U. foliosa L.; (F, I) U. flaccida A.DC.; (G) U. laciniata A.St.-Hil. \& Girard; (H) U. dichotoma Labill.; (J, K) U. geminiloba Benj. (B - Photo credit to Gabriel Sabino).

rps12, trnL-trnF, ITS1, and ITS2 spacers, encoding genes rbcL, matK, and structural gene $5.8 \mathrm{~S}$ ). This allowed us to evaluate the different intrinsic traits of each marker due to their nature and evolutionary history. The $r b c L$ gene showed the lowest proportion of variable sites, and its conservation (Palmer et al., 1988; Shivakumar et al., 2016) is given to the metabolic significance as ribulose bisphosphate carboxylase-oxygenase (Rubisco) as the core autotrophic carboxylase in oxygenic photosynthetic organisms (Raven, 2013). In contrast, ITS showed the highest proportion of variable sites, mostly resulting from the ITS1 and ITS2 spacers; the former with more variable sites (including indels) than the later. The ITS had the lowest consistency index (0.43) to this dataset (Table 3), due to the high concentration of homoplasies, but still contained a phylogenetically useful signal.

The rps16 and trnL-trnF datasets had the most highly supported ( $>50 \%$ ) clades in trees (Fig. 3), and was therefore important for providing a signal for the phylogenetic hypothesis. In spite of $r b c L$ having 


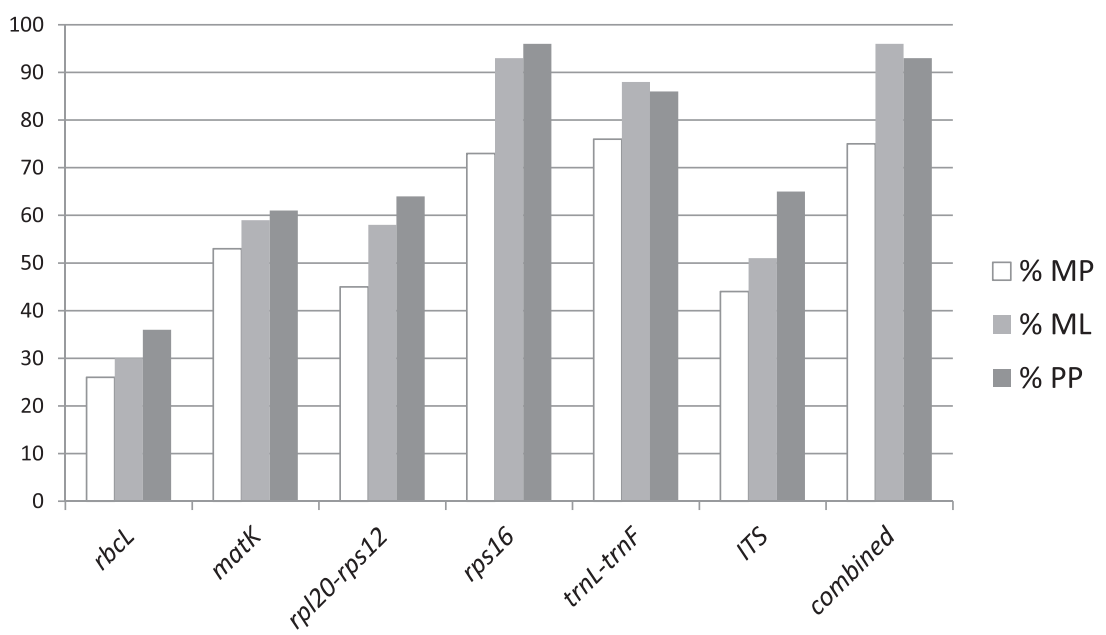

Fig. 3. Proportion of supported clades based on maximum parsimony, maximum likelihood, and Bayesian approaches to each DNA dataset (see also Table 3). the highest retention index (0.92; Table 3), as a result of most variable sites supporting as synapomorphies, this dataset also had the lowest proportion of supported clades (Table 3; Fig. 3), and this result is evident in the trees based on maximum parsimony, maximum likelihood, and Bayesian approaches (Fig. 5). The rps16 intron, with the combined datasets, resulted in the highest proportions of supported clades (Table 3; Fig. 3), corroborating the use of this intron as an important marker for phylogenies (Downie and Katz-Downie, 1999; Jobson and Albert, 2002; Jobson et al., 2003).

\subsection{Phylogenetic relationships of major clades within Lentibulariaceae}

The three genera of Lentibulariaceae, Pinguicula, Genlisea, and Utricularia are well established regarding the both taxonomic and phylogenetic approaches. The three genera are monophyletic, strongly supported by different sources of data, both morphological and molecular (Jobson and Albert, 2002; Jobson et al., 2003; Müller et al., 2004). Pinguicula comprises species with a common archetypal body organization of angiosperms, with vegetative organs including usually a short stem with helicoidally arranged leaves, and roots (Casper, 1966; Roccia et al., 2016). On the other hand, Genlisea and Utricularia have concentrated drastic evolutionary changes in body organization, with a deviation from the classical root-shoot (CRS) architectural rules or bauplan (Rutishauser, 2016) typically found in seed plants.

The Lentibulariaceae are carnivorous plants that commonly grow in nutrient-poor habitats (Adamec, 1997; Juniper et al., 1989). Pinguicula species have flypaper traps, with leaves covered by glandular trichomes (Casper, 1966; Heslop-Harrison, 2004). Genlisea species have leaves arranged in rosettes with heterophyllous leaves: photosynthetic and achlorophyllous leaves. These latter are specialized structures called rhizophylls that show positive geotropism (Fleischmann, 2012a). The rhizophylls are subterranean Y-shaped and tubular leaves, acting to fix the plants in the soil and also to trap small organisms (Płachno et al., 2008) as a source of nutrients (Barthlott et al., 1998). Utricularia species also possess foliar traps, which are called utricles. These are hollow bladders, usually 1-6 mm long with elastic walls and with mobile trap door (Vincent et al., 2011). Utricularia and Genlisea are the most divergent lineages within Lentibulariaceae, and they form a well-supported sub-clade sister to the Pinguicula clade (Jobson and Albert, 2002; Jobson et al., 2003; Müller et al., 2004; Fig.4).

\subsection{Phylogenetic relationships within Utricularia}

Here we show that subgenus Polypompholyx is the sister group to the clade formed by subgen. Utricularia and Bivalvaria according to the combined sequences (Fig. 4) and also individual matK, rps16 intron and trnL-F datasets (supplementary material). According to $r b c L$, rpl20-rps12 and ITS datasets (supplementary material), our phylogenetic reconstruction places the three subgenera in an unresolved polytomy. Previous studies based on trnL-F spacer, rps16 intron (Jobson and Albert, 2002; Jobson et al., 2003; Reut and Jobson, 2010), and on matK (Silva et al., 2016) also support this tree topology (Polypompholyx, (Bivalvaria, Utricularia)); although Müller and Borsch (2005) had placed subgen. Polypompholyx as a sister group to subgen. Bivalvaria, and both as sister group to subgen. Utricularia. The incongruence found between studies may be due to taxonomic sampling, considering that these previous studies sampled no $>50$ species of Utricularia, some of them with less than $15 \%$ of the Utricularia species.

According to our hypotheses based on combined and isolated DNA datasets, subgenus Polypompholyx is monophyletic and comprises the two clades of sect. Pleiochasia and sect. Polypompholyx; which supports Reut and Jobson (2010). Considering the pollen, Lobreau-Callen et al. (1999) recognized shared characters of both sections (classified as pollen type 1) and Taylor (1989) also considered this mostly tricolporate pollen type, present in sect. Polypompholyx, Tridentaria, and Pleiochasia, as the most primitive within the genus.

Section Benjaminia is monotypic and comprises the single South American species Utricularia nana. Phylogenetic studies reveal the incongruence of its phylogenetic position. Jobson et al. (2003) state that sect. Oligocista is paraphyletic, since it includes sect. Benjaminia. However, Müller and Borsch (2005) and Müller et al. (2006) positioned the group as sister to Oligocista + Avesicarioides. The results presented in this study, corroborated for all single and combined DNA datasets and with high support, support the paraphyly of sect. Oligocista; with sect. Stomoisia as sister group of the clade formed by the sections Benjaminia and Oligocista. Furthermore, Komiya (1973) proposed a new subgenus Simplicirostra containing sections Orchidioides, Stomoisia, Avesicarioides, and Setiscapella, based mainly on characters related to life form, utricles, and the morphology of reproductive structures (inflorescences, flowers and bracts/bracteoles). Although it is evident that there is no close relationship with sect. Orchidioides and/or Setiscapella, in the analysis based on matK, sect. Oligocista is revealed as paraphyletic too (also verified by Jobson et al., 2003), since sect. Avesicarioides, represented in this study by $U$. rigida (type species for the section), is nested within Oligocista. Taylor (1989) suggested the close relationship between sections Oligocista and Benjaminia, but justified their separation based on the morphology of the calyx lobes and utricles (shape and the lack of oral appendages). Here we propose combining both sections, as a single section, applying the oldest available name, sect. Oligocista.

The results presented here corroborate the inclusion of Utricularia pubescens (Fig. 1) in sect. Calpidisca. Taylor (1986) proposed the monotypic section Lloydia exclusively to accommodate this polymorphic species which is widely distributed in tropical America and Africa. It has diagnostic features, such as the peculiar peltate leaves (a 


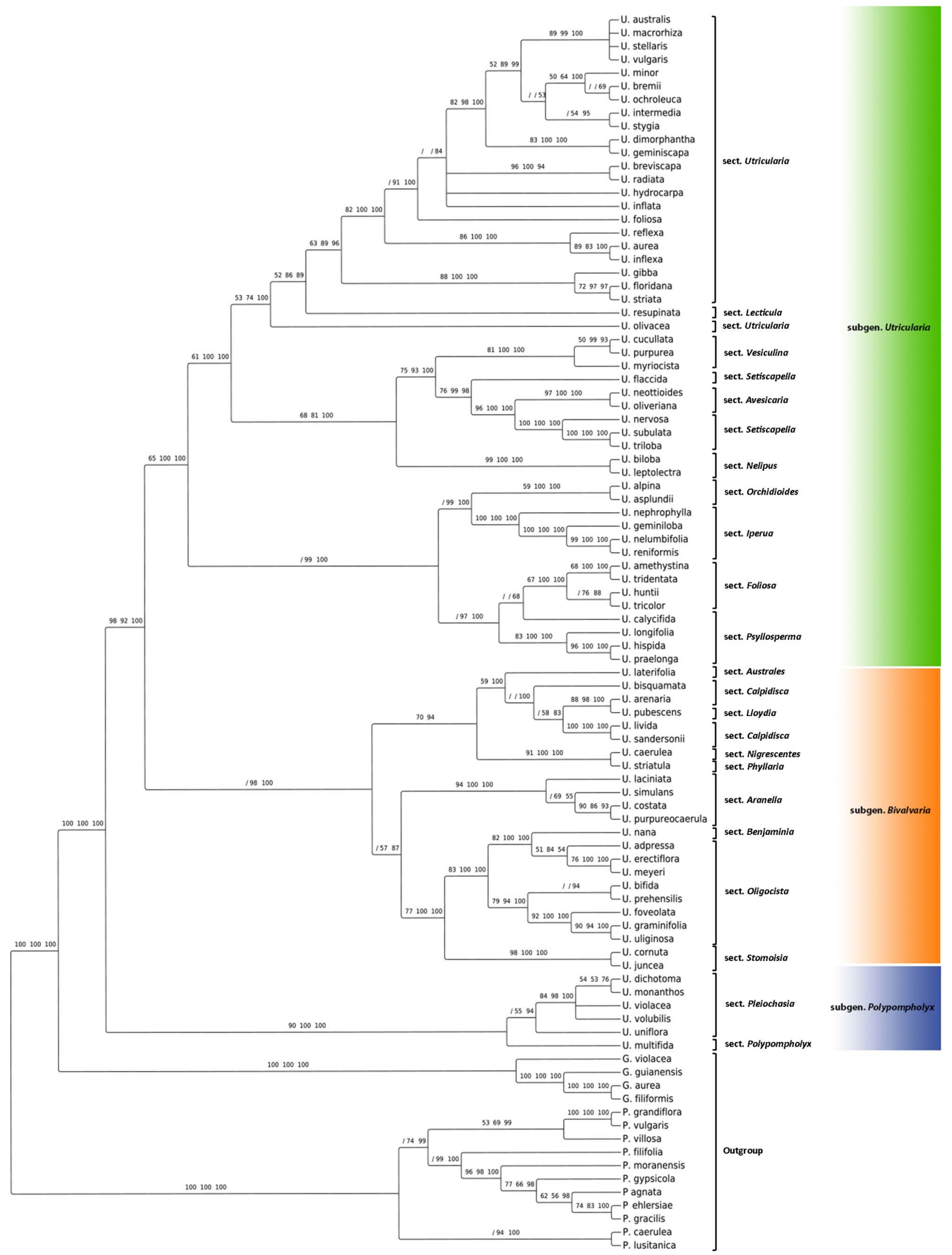

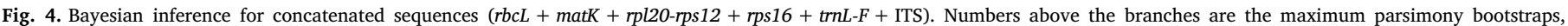
maximum likelihood bootstraps and posterior probabilities. (/denotes branches with a support value <50; U. = Utricularia; G. = Genlisea; P. = Pinguicula). 
Table 4

Divergence times estimation (Mya) for selected nodes of Utricularia. (see also Fig. 7).

\begin{tabular}{lll}
\hline Node & $\begin{array}{l}\text { Age according to this } \\
\text { study (mya; 95\% HPD) }\end{array}$ & $\begin{array}{l}\text { Age according to } \\
\text { Ibarra-Laclette et al. } \\
\text { (2013) }\end{array}$ \\
\hline $\begin{array}{ll}\text { Gen. Pinguicula } \\
\text { Genlisea-Utricularia clade }\end{array}$ & $\begin{array}{l}\text { 39.39 (7.27-27.74) } \\
\text { Gen. Utricularia }\end{array}$ & 9.87 \\
subg. Polypompholyx and & $30.35(17.12-45.86)$ & 36.00 \\
$\quad$ Bivalvaria & $26.94(14.80-41.39)$ & - \\
subg. Polypompholyx & $17.62(6.53-30.20)$ & 15.45 \\
subg. Bivalvaria & $24.98(13.17-38.52)$ & 27.20 \\
subg. Utricularia & $26.60(15.13-39.97)$ & 25.63 \\
sect. Utricularia & $12.76(8.15-18.99)$ & 11.11 \\
\hline
\end{tabular}

very rare trait in the genus, present only also in U. nelumbifolia), and the morphology of the bracts, bracteoles and seeds. However Taylor (1989) also mentions that all other morphological characteristics of the plant, particularly the morphology of the utricles, support its inclusion in sect. Calpidisca, which is corroborated by our results based on molecular data. Thus, we suggest here that $U$. pubescens belongs in sect. Calpidisca.

Muiller et al. (2006) argue that if they had sampled more species of sect. Aranella in their phylogenetic analyses, then probably, the section would have been proven to be polyphyletic. However, data from this research indicate that sect. Aranella is monophyletic and, according to the combined analysis, the section is closely related to sections Benjaminia, Oligocista and Stomoisia (Fig. 4).

Our concatenated tree results indicate that sect. Psyllosperma is clearly paraphyletic, supporting the results of Müller and Borsch (2005). For the ITS region, the species of this section form a monophyletic group, however the clades have low support. For the combined and matK datasets, sect. Psyllosperma forms a paraphyletic clade and $U$. calycifida (sect. Psyllosperma) is nested in the clade of sect. Foliosa, as also demonstrated by Jobson et al. (2003) and Müller and Borsch (2005). Taylor (1986) proposed sect. Psyllosperma as an apparently "natural" group, even considering the similarity in pollen and seeds (Menezes et al., 2014) between the species of both sections (Psyllosperma and Foliosa). Müller and Borsch (2005) suggested the expansion of sect. Foliosa to include the sect. Psyllosperma - a proposal that is totally supported by this study.

Sect. Iperua is paraphyletic with Orchidioides based on the matK dataset, as also indicated by previous phylogenies (Müller et al., 2004; Müller and Borsch, 2005; Rodrigues et al., 2017). This might suggest that sect. Iperua should be included in sect. Orchidioides. Yet, the combined analysis (Fig.4) did not show this paraphyly, however $U$. humboldtii was not sampled in this analysis. Thus, according to previous studies (Müller and Borsch, 2005; Rodrigues et al., 2017) and based on the matK dataset, sect. Orchidioides should be expanded to include the sect. Iperua, since both compose a monophyletic group.

Phylogenies retrieved to date suggest that sect. Vesiculina is closely related to sect. Setiscapella. However, for the data presented, sect. Vesiculina is sister to Setiscapella + Avesicaria, except for the ITS region where sect. Vesiculina has been revealed as sister to sect. Foliosa; however, this is only supported by Bayesian analysis. Sect. Setiscapella is paraphyletic according to matK region, as in Jobson et al. (2003), however this occurrence cannot be confirmed by other regions since $U$. flaccida was not sampled for all markers.

\subsection{Relationships among species of section Utricularia}

Sect. Utricularia is the largest section in number of species, formally with 34 species sensu Taylor (1989), but totaling 36 taxa with Utricularia stygia Thor and U. tenuicaulis Miki (Fleischmann 2012b). Here we sampled 23 species of sect. Utricularia, the largest sample ever represented when compared to previous phylogenetic studies. The section is sister to sect. Lecticula, corroborating Jobson et al. (2003) and, according to Taylor (1989), has common morphological features including trap morphology, the ovoid shape with two simple appendices beside the mouth, prismatic seeds with isodiametric testa and oblate, 9-13 colporate pollen. According to our analyses, sect. Utricularia is divided into two major clades, clade I with the species $U$. gibba, $U$. floridana and $U$. striata, and another clade II with the remaining species.

Utricularia gibba is a cosmopolitan suspended aquatic species with extreme morphological polymorphism. Taylor (1989) highlights the similar morphology to $U$. floridana and $U$. striata, except for the leaves and seeds. The different datasets support this close relationship with the three species as a monophyletic group. Clade II can be subdivided into two subclades, one of them represented by $U$. aurea, $U$. inflexa and $U$. reflexa, which is highly supported by the combined analysis (Fig. 4) and rpl20-rps12 dataset.

Considering the isolated datasets, some incongruence was found in the groups formed by species Utricularia australis, U. bremii, U. dimorphanta, U. geminiscapa, $U$. intermedia, $U$. macrorhiza, $U$. minor, $U$. ochroleuca, $U$. stellaris, $U$. stygia and $U$. vulgaris. Based on the chloroplast spacers trnT-trnL and trnS-trnQ, Kameyama et al. (2005) considered that $U$. australis originated from an asymmetric hybridization event between $U$. australis $\mathrm{f}$. tenuicaulis $(=U$. tenuicaulis) and $U$. macrorhiza; which remains plausible based on our chloroplast spacer datasets. Some European species, such as $U$. australis, $U$. bremii, $U$. ochroleuca, $U$. stygia, are sterile and no longer cross-pollinate (Beretta et al. 2014), their propagation is predominantly clonal, which probably reduces genetic variability which possibly leads to the polytomy observed between closelyrelated species.

According to the combined analysis (Fig. 4) and $r b c L$ dataset, sect. Utricularia is not monophyletic due to the free-floating aquatic species $U$. olivacea. This American species is minute and also taxonomically curious plants with scarce information available (Beal and Quay, 1968; Trevisan and Moço, 2011). Moreover, the matK tree nested U. olivacea within sect. Utricularia (as also shown by Müller and Borsch (2005) and Silva et al. (2016)) and in the same clade with $U$. gibba and $U$. floridana. While the $r b c L$ sequence was newly generated for this study, we used the matK sequence of $U$. olivacea from GenBank (and the same used by Müller and Borsch (2005) and Silva et al. (2016)) for our phylogenetic constructions. $U$. olivacea can be found in close association with other Utricularia species (Taylor, 1989) and also with U. gibba (personal observation). Thus, contamination by $U$. gibba in $U$. olivacea samples cannot be excluded and further detailed study is needed, including more plant samples and also DNA markers.

The $r b c L$ partial paleosequence found in the rumen of a Holocene Yakutian bison nested within the Utricularia sect. Utricularia clade (Fig. 7, U. "bison") and a confident identification to which species this DNA sample might belong was not possible.

\subsection{Evolution of Utricularia life forms}

Bladderworts are usually found in wet soils in open areas, ponds and lakes, streams, and on rocks or tree trunks (Taylor, 1989). They colonize different environments, from land (with terrestrial, lithophyte and epiphyte species) to open water (with free-floating and affixed aquatic species, rheophytes, and epiphytes - in the latter case on tree trunks as $U$. jamesoniana and $U$. quelchii (sect. Orchidioides), or even as aquaticepiphytes in bromeliad tanks, as is the case of $U$. nelumbifolia (Płachno et al., 2017), U. humboldtii, and U. reniformis (sect. Iperua; Taylor, 1989). Some species may occupy different environments and thus can be classified in different categories (Utricularia alpina can be terrestrial and epiphytic - e.g. Valdés, 2008; U. reniformis can be terrestrial, epiphytic or even lithophytic, and $U$. gibba, which is commonly aquatic and has also be found on emergent and submerged leaves of Salvinia, a common fern found in ponds, and thus can be considered as an epiphyte - personal observation). Although this broad ecological amplitude cannot properly be generalized for all Utricularia species, this can be a complicating factor in assessment and discrete categorization of the life 


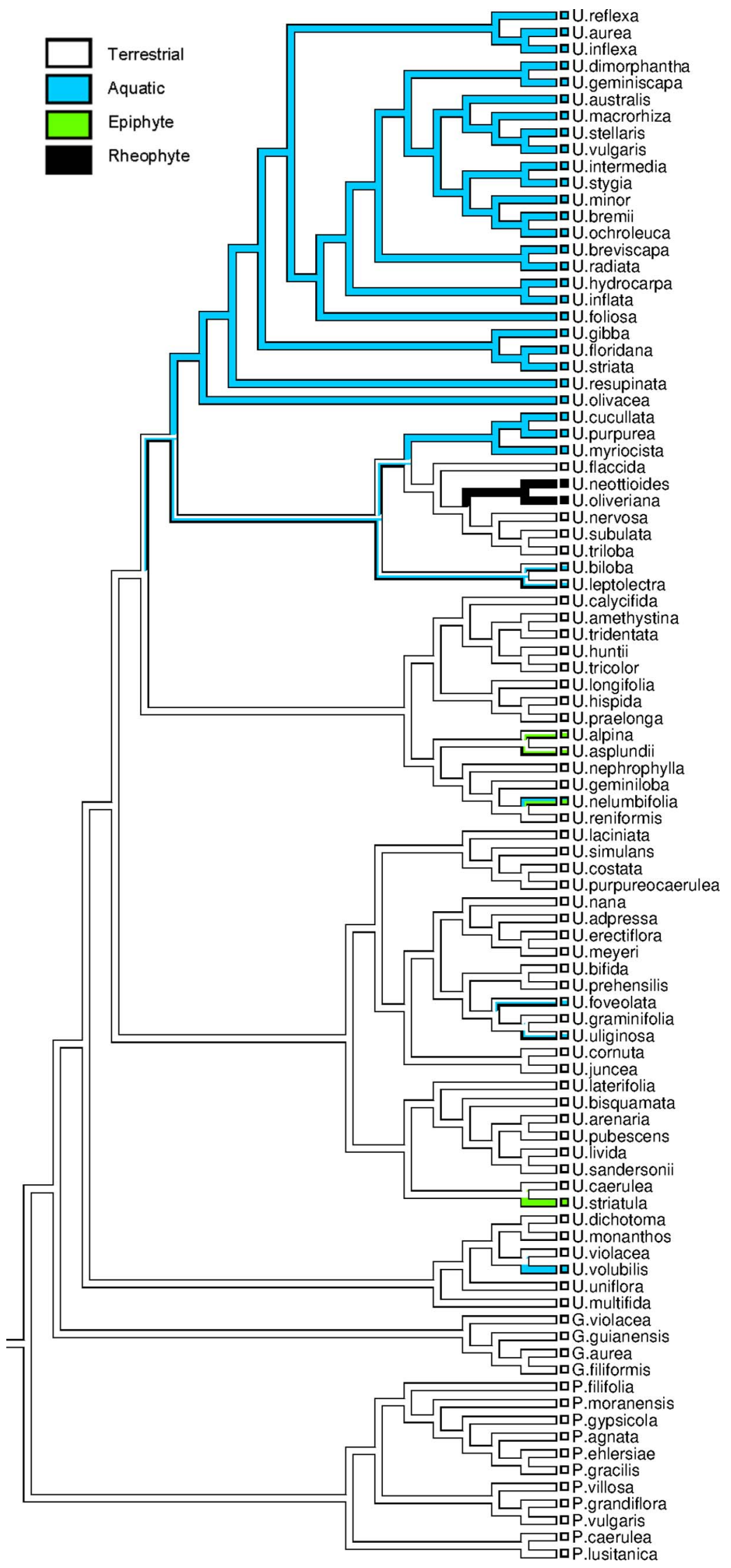

Fig. 5. Distribution of the life forms of Lentibulariaceae, with focus on Utricularia species, based on the Bayesian combined tree. (U. = Utricularia; G. = Genlisea; P. = Pinguicula 


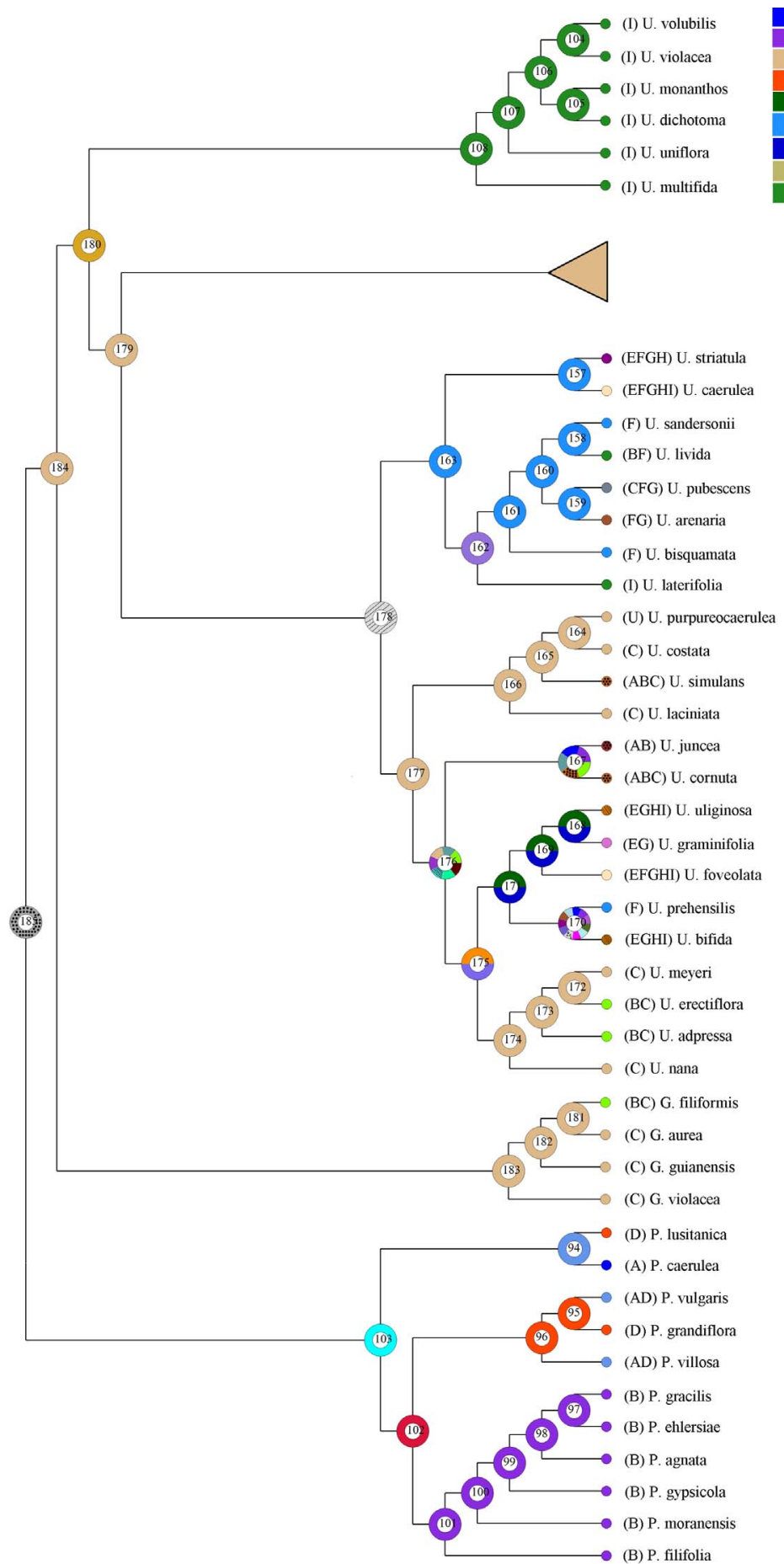

A - North America B - Central Americ C - South America

D - Europe, North Africa

E - North Asia

F - Africa (south Sahara), Madagascar

G - Tropical Asia

$\mathrm{H}$ - Malaysia

- Australia, New Caledonia, New Zealand

$\longrightarrow(\mathrm{BC}) \mathrm{U}$. trilob
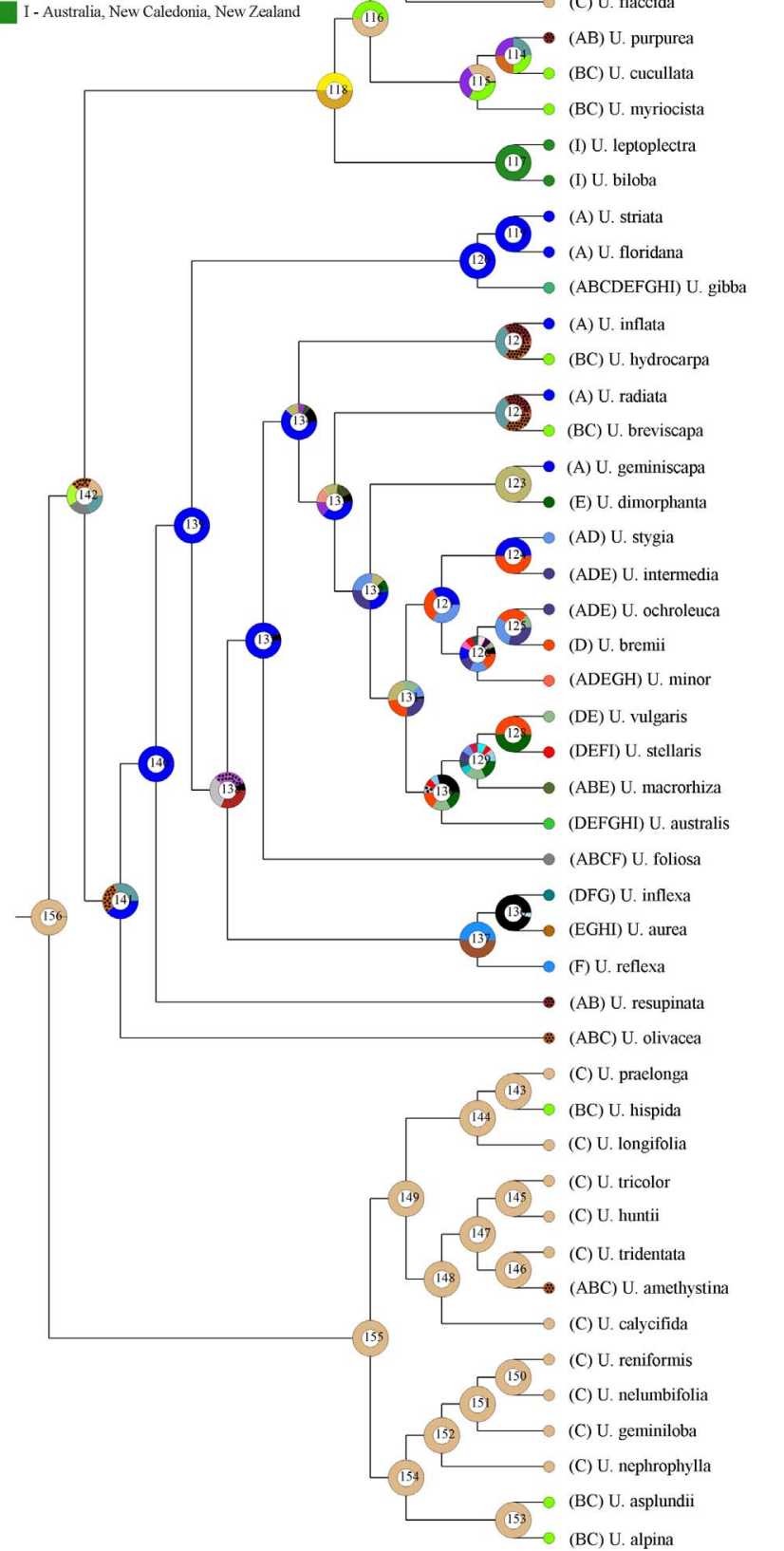

\begin{tabular}{|c|c|c|c|c|c|c|c|c|c|c|c|c|c|c|c|c|}
\hline AB & ABCDEFGHI & $\mathrm{ABCF}$ & $A B D E$ & ACE & $A D$ & AF & $B C$ & BCI & $\mathrm{BF}$ & CFG & DE & DEFI & EF & EFGHI & EFHI & 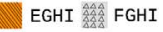 \\
\hline$=A B C$ & ABCDFGHI & $\mathrm{ABCI}$ & ABE & ACG & ADE & AFG & DLL & BD & CE & CG & DEF & 进 DEI & EFG & EFGI & EFI & $F G$ \\
\hline$A B C D$ & ABCE & $A B D$ & $\mathrm{AC}$ & ACI & ADEC & AG & BCG & BDE & $\mathrm{CF}$ & CI & DEFGHI & DFG & EFGH & EFH & EG & FGH \\
\hline
\end{tabular}

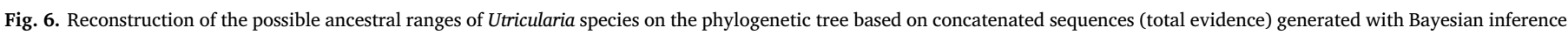

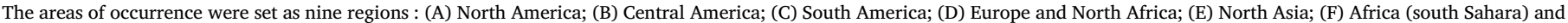
Madagascar; (G) Tropical Asia; (H) Malaysia; and (I) Australia, New Caledonia, and New Zealand.

and fuzzy "Arberian" morphology (Arber, 1950; Rutishauser, 1999; Rutishauser and Isler, 2001). The developmental switches and plasticity to unusual vegetative morphologies, comparable only to the Podostemaceae (river-weeds), has possibly facilitated the evolution of species diversity (Rutishauser, 2016) and an adaptation to and colonization of different habitats.
According to our phylogenetic hypothesis, and also supported by previous phylogeny studies (Jobson and Albert, 2002; Jobson et al., 2003; Müller et al., 2006), the terrestrial habit is plesiomorphic for the family Lentibulariaceae, as a common life form for most Pinguicula (Casper, 1966) and Genlisea species, with a few shifts to aquatic life form in Genlisea (e.g. G. angolensis, G. guianensis; Fleischmann, 2012a). 


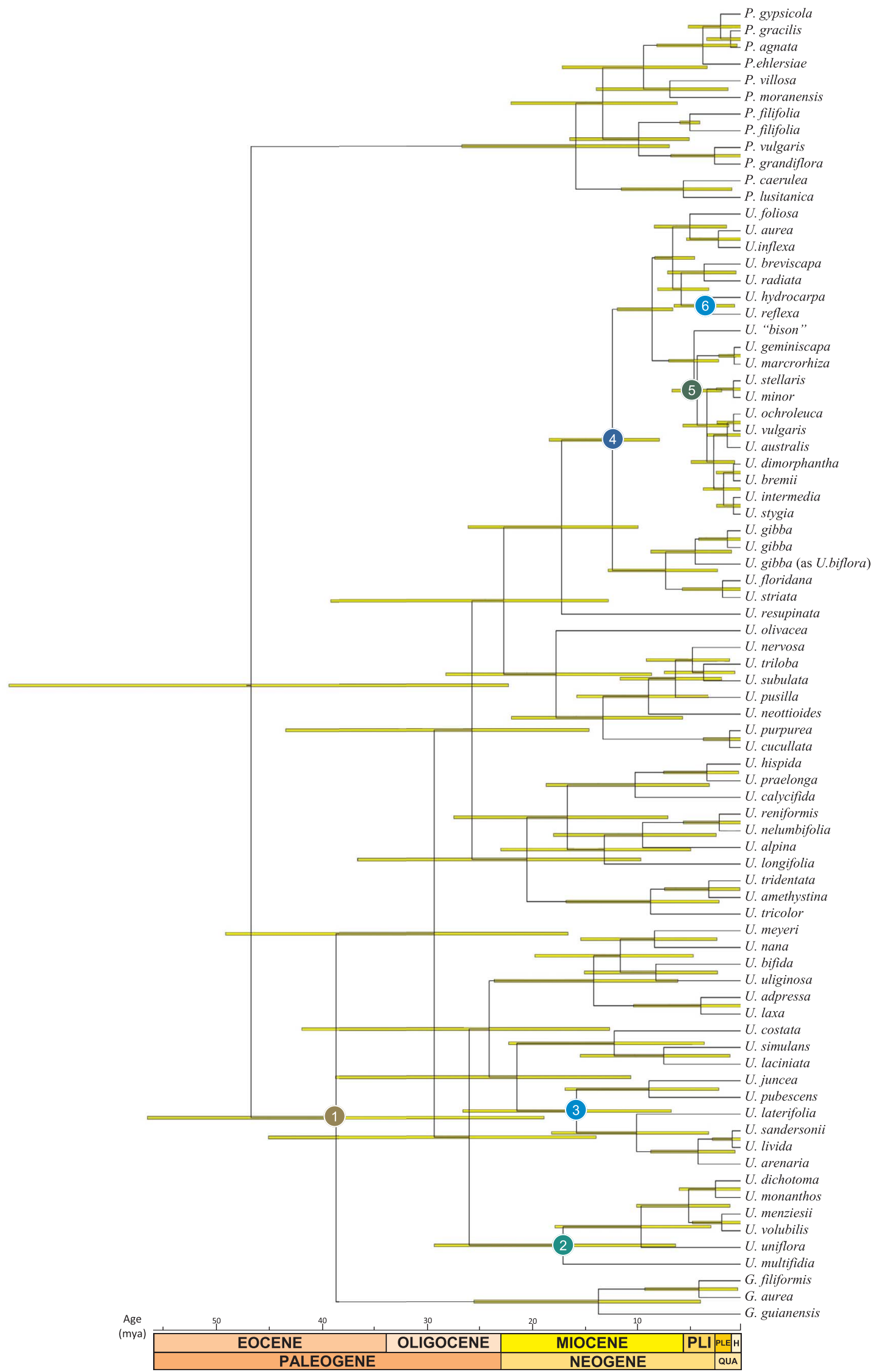

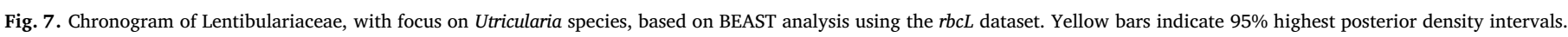
Nodes of interest were marked as 1-6 (see also Fig. 8). (PLI = Pliocene; PLE = Pleistocene; $\mathrm{H}=$ Holocene.) 


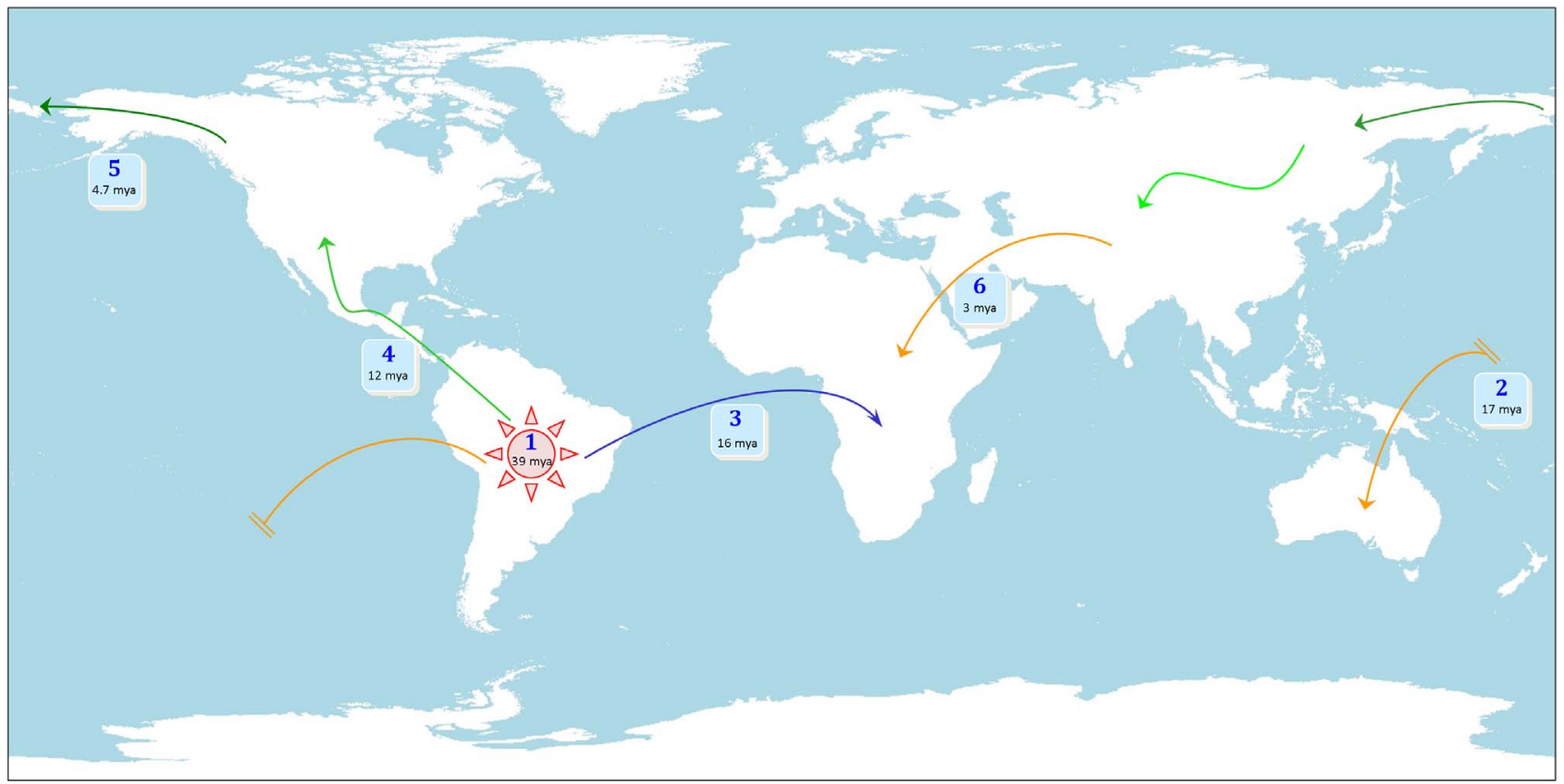

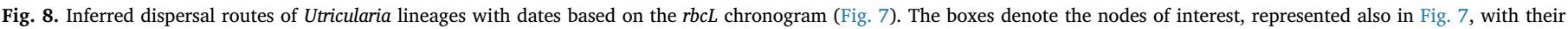
respective possible ages.

For the Genlisea + Utricularia clade, this pattern was inherited and represents the most common life form for the various lineages of Utricularia - subgenera Polypompholyx, Bivalvaria and Utricularia (Guisande et al., 2007). Species with this pattern are usually found in peaty, sandy or even stony environments, but require high levels of humidity for their growth (Taylor, 1989).

Perhaps one of the most intriguing life forms is that of rheophytes. This habit is characterized by plants adapted to living in shallow rivers and streams (Font Quer, 1953). The shoots are strongly attached to rock surfaces by very specialized organs called appressoria that are lignified shoot projections which are responsible for anchoring the plants in even very rapid streams. This habit, studied extensively by Steenis (1978), is quite rare in Utricularia and is represented by a few species, including sect. Avesicaria (with the Neotropical species $U$. neottioides (Adamec et al., 2015) and $U$. oliveriana), Avesicarioides (with the African species $U$. rigida and $U$. tetraloba; the former represented in this study by matK sequence), sect. Mirabiles (U. heterochroma and U. mirabilis), and sect. Choristothecae ( $U$. choristotheca and $U$. determannii). From a phylogenetic perspective, the rheophytic habit appeared at least twice in the evolutionary history of Utricularia (Müller and Borsch, 2005): once in the lineage of the African sect. Avesicarioides (U. rigida and U. tetraloba) and the other in the South American sect. Avesicaria (U. neottioides and U. oliveriana; Fig. 5). Thus, it is possible to see two homoplastic processes of parallel evolution when both rheophytic origins have the terrestrial life form as ancestral conditions. The epiphytic form also evolved at least twice from terrestrial species in the sections Iperua and Orchidioides (Fig. 5).

The aquatic life form is the second most common of all Utricularia species -the terrestrial form is the most common (Guisande et al., 2007; Taylor, 1989). Most aquatic species are from sect. Utricularia, which presents different subtypes of this life form (freely floating and affixed forms, living near the water surface commonly as amphibious or even semi-terrestrial or in a deeper water column). According to our phylogenetic hypotheses, the aquatic life form was derived from the terrestrial one and evolutionary shifts might have occurred more than once within the genus Utricularia (Fig.5). This scenario supports the hypothesis of multiple colonization of the aquatic environment, which should have been easy given the phenotypic plasticity of Utricularia and the fact that the traps work in water (Juniper et al., 1989; Taylor,
1989).

\subsection{Phylobiogeography of Utricularia}

Utricularia is a cosmopolitan genus distributed in all continents, except within the Antarctic Circle, most deserts, and most oceanic islands. Their presence on remote, oceanic islands, such as Galapagos and Hawaii, is possibly due to an accidental introduction (Taylor, 1989). The boreal boundary for the genus is represented by $U$. intermedia, $U$. minor, and $U$. vulgaris in the Arctic Circle (transgressing $70^{\circ} \mathrm{N}$ ). The southern boundary is represented by $U$. monanthos that extends to near $47^{\circ} \mathrm{S}$ in wet soils and streams with shallow water in New Zealand (Taylor, 1989).

The genus Utricularia is represented by around 240 species and the species-richest regions occur mainly in tropical zones, with most taxa concentrated in South America (around 80 species, mainly in Southeast to Northeast Brazil and the Guyana Shield), and Australia, New Zealand and Central America, represented by around 70 species, and Tropical Asia, with around 50 species (McPherson, 2010; Taylor, 1989). South America and Australia are also the regions with the highest concentration of endemic species (76\% of the Australian and $65 \%$ of the South American Utricularia species are endemic). The African continent has the third highest species richness (around 40 species), with taxa distributed throughout the continent (except the Sahara Desert) and Madagascar (McPherson, 2010; Taylor, 1989).

Studies on biogeography including chronologies of Utricularia are notably scarce, mainly due to a lack of fossils for confident calibrations. Ibarra-Laclette et al. (2013) inferred a molecular clock estimate based on trnL, rps16, coxI and maK sequences and applied as a calibration point the divergence time of the common ancestor of Pinguicula and Utricularia-Genlisea clade, which was estimated at 42 million years ago (mya) based on a relaxed molecular clock (Bell et al., 2010). Here we propose a molecular clock tree based on $r b c L$ sequences and calibrated by using two references: (i) fossilised pollen of $U$. minor (dated between 11.6-23.0 mya; Muller, 1984) and (ii) the insular separation of the island Isla de la Juventud from the Western portion (Pinar del Río province) of Cuba (1.8-5.3 mya) and resulting divergence of Pinguicula filifolia lineages (Ferrera et al., 1990). The chronological tree presented here (Fig. 7) resulted in similar divergence times in general when 
compared to Ibarra-Laclette et al. (2013). The time estimates for each clade throughout the discussion are from our present study and also from Ibarra-Laclette et al. (2013; both values in parentheses in mya).

According to our results (also suggested by Jobson et al., 2003 and Fleischmann et al., 2011), the last common ancestor of Genlisea-Utricularia clade was possibly a South American lineage, that arose 39 mya (36 mya estimated by Ibarra-Laclette et al., 2013) (Figs. 6-8). Utricularia diverged from its sister genus 30 mya (31 mya according to IbarraLaclette et al., 2013) and dispersed to Australia with the lineage represented by subgenus Polypompholyx (17 mya by our estimate and 15 by Ibarra-Laclette et al., 2013) and possibly to Africa afterwards (16 mya; 21 mya by Ibarra-Laclette et al., 2013). Probably other transcontinental dispersals may have occurred, one of them represented by sect. Nelipus that includes three Australian, Tropical Asian and Malaysian species ( $U$. biloba, $U$. limosa, and $U$. leptoplectra).

The dispersal to North America possibly occurred from South America, between 11 mya (Ibarra-Laclette et al., 2013) and 12 mya (this study; Figs. 6-8), in the middle of Miocene, even with the land discontinuity between North and South America as a reason of the absence of Isthmus of Panama that arose some million years later in Pliocene around 2.8 mya (O'Dea et al., 2016). North America has been colonized by species that are widespread also in Central and South America, such as $U$. amethystina, $U$. cornuta, $U$. juncea, $U$. olivacea, $U$. purpurea and $U$. resupinata (Taylor, 1989).

The colonization of Utricularia into Eurasia probably occurred via the Bering Strait (DeChaine, 2008) to Northwestern Asia and also to Europe at around 4.7 mya by long-distance dispersal (Figs. 6-8), and this hypothesis can be corroborated considering the occurrence of hibernacula in $U$. minor in tropical Alpine Papua New Guinea, probably distributed by migratory birds (Taylor 1977). Also, the hypothesis of trans-Atlantic dispersal cannot be excluded (Abbott and Brochmann, 2003). The presence of $U$. intermedia, $U$. macrorhiza and $U$. ochroleuca in North American and Eurasian floras (Taylor, 1989) may corroborate the hypothesis of an American origin of Eurasian lineages responsible for spreading through Europe and southern Asia. The presence of $U$. aurea, $U$. inflexa and $U$. reflexa nested within sect. Utricularia is particularly intriguing, although they have been classified in this section (Taylor, 1989). Utricularia reflexa is a highly variable suspended aquatic species restricted to Africa which, together with other species from this section, represents a group mostly composed of species from Americas and Europe. According to our estimate (Figs. 6 and 7), the lineage of $U$. aurea, $U$. inflexa and $U$. reflexa possibly reached the African continent from Tropical Asia very recently, around 3 mya, which would be strongly supported if $U$. corneliana (Jobson, 2012) was indeed $U$. reflexa (Fleischmann, 2015).

The extensive geographic range of the genus and also of some species such as Utricularia gibba and U. subulata, which have a pantropical distribution (Taylor, 1989), may be at least partly due to long dispersal by migratory birds, facilitated by the morphology of seeds most species of Utricularia have diminutive dust-like seeds (Eriksson and Kainulainen, 2011; Menezes et al., 2014) with a very reduced embryo (Płachno and Świątek, 2010).

The very small seeds in several species contain a foveolate testa or projections formed by periclinal walls (e.g., see U. reniformis - Płachno et al., 2009). These traits, when combined with the small seed size, are favorable for the formation of air bubbles, thereby providing buoyancy and aiding in seed dispersal (Menezes et al., 2014). Many species of Utricularia are found in bogs and hydromorphic soils, usually associated with seasonal water bodies or streams arising from rain - habitats very favorable for water dispersion. Also, wind dispersal may be the main process for species as $U$. humboldtii, $U$. nelumbifolia, and $U$. reniformis (Taylor, 1989).

Vegetative propagules, known as winter buds or turions are present in 12 temperate or subtropical species, are dormant overwintering storage organs formed by modified shoot apices with reduced leaves, rich in starch or proteins (Płachno et al., 2014). Turions resist dessication and may provide a means of long-distance disersal on the feet of water birds flying between lakes. Stolon fragmentation may also play an important role for species dispersal, a very common and efficient manner to rapidly colonize new water bodies. Stolon fragmentation of aquatic species (such as U. cucullata, U. foliosa - Fig. 2, U. reflexa) is very important for dispersal and also for colonization, especially if the habitats are seasonal water bodies created by rain water. Each small stolon fragment (which may be $<1 \mathrm{~cm}$ long, as is common for $U$. gibba) can produce a much-divided new plant in a few weeks. Dispersal and colonization using clonal reproduction are a rapid and efficient process for aquatic angiosperm reproduction and, when associated with the possible long-distance dispersal (Les et al., 2003), can at least partly explain the pantropical distribution of $U$. gibba. An extensive population study of $U$. gibba based on ortholog and paralog copies of rDNA ITS, which surveyed inter and intrapopulational individuals from Brazil and Cuba, showed that Cuban plants share haplotypes from individuals sampled in Northeast Brazil. These results support the rapid northward dispersion hypothesis of this species in the Americas, probably facilitated by clonal reproduction.

\section{Funding}

This work was supported by Unesp/PROPe and CAPES Coordenação de Aperfeiçoamento de Pessoal de Nível Superior [fellowship for SRS]; Conselho Nacional de Desenvolvimento Científico e Tecnológico (CNPq) for the fellowship [Bolsa de Produtividade - Grant No. \# 309040/2014-0 for VFOM]; and Czech Long-term research development project No. RVO 67985939 [for LA].

\section{Acknowledgements}

We thank Dr. Bas van Geel (Institute for Biodiversity and Ecosystem Dynamics, University of Amsterdam, The Netherlands), Dr. Barbara Gravendeel and Dr. Youri Lammers (Naturalis Biodiversity Center, Leiden, The Netherlands) for providing and permitting the use of the $r b c L$ paleosequence of Utricularia found in the rumen of the Holocenic bison. We also thank Alessandro de M. Varani, Eduardo C. Gasparino, Cristine G. Menezes, Janete A. Desidério, Maurício Bacci Jr., Manoel Victor F. Lemos and colleagues from Laboratory of Plant Systematics for fruitful discussions for improvement of this paper and also to Gabriel Sabino for kindly providing the picture of $U$. pubescens. Sincere thanks are due to Brian G. McMillan (Glasgow, Scotland, U.K.) for correction of the language and the anonymous reviewers for the comments and suggestions which helped us to improve the manuscript. The collecting permits were ICMBio/MMA/SISBIO \#26938 and \#48516 (Brazil) and SL100552 and SL007174 (Australia).

\section{Appendix A. Supplementary material}

Supplementary data associated with this article can be found, in the online version, at http://dx.doi.org/10.1016/j.ympev.2017.10.010.

\section{References}

Abbott, R.J., Brochmann, C., 2003. History and evolution of the arctic flora: In the footsteps of Eric Hultén. Mol. Ecol. http://dx.doi.org/10.1046/j.1365-294X.2003. 01731.x.

Adamec, L., 1997. Mineral nutrition of carnivorous plants: a review. Bot. Rev. 63, 273-299. http://dx.doi.org/10.1007/BF02857953.

Adamec, L., Fleischmann, A., Pásek, K., 2015. Biology of the trapless rheophytic Utricularia neottioides: is it possible to grow this specialized species in cultivation? Carniv. Plant Newsl. 44, 104-114.

Adamec, L., Sirová, D., Vrba, J., Rejmánková, E., 2010. Enzyme production in the traps of aquatic Utricularia species. Biologia (Bratisl) 65, 273-278. http://dx.doi.org/10. 2478/s11756-010-0002-1.

Akaike, H., 1973. Information theory and an extension of the maximum likelihood principle. In: International Symposium on Information Theory. pp. 267-281. http:// dx.doi.org/10.1016/j.econlet.2011.12.027.

Albert, V.A., Jobson, R.W., Michael, T.P., Taylor, D.J., 2010. The carnivorous 
bladderwort (Utricularia, Lentibulariaceae): a system inflates. J. Exp. Bot. 61, 5-9. http://dx.doi.org/10.1093/jxb/erp349.

Arber, A., 1950. Natural Philosophy of Plant Form. Cambridge University Press.

Barthlott, W., Porembski, S., Fischer, E., Gemmel, B., 1998. First protozoa-trapping plant found. Nature 392, 447.

Bell, C.D., Soltis, D.E., Soltis, P.S., 2010. The age and diversification of the angiosperms re-revisited. Am. J. Bot. 97, 1296-1303. http://dx.doi.org/10.3732/ajb.0900346.

Beretta, M., Rodondi, G., Adamec, L., Andreis, C., 2014. Pollen morphology of European bladderworts (Utricularia L., Lentibulariaceae). Rev. Palaeobot. Palynol. 205, 22-30.

Beal, E.O., Quay, T.L., 1968. A review of Utricularia olivacea Wright ex Grisebach (Lentibulariaceae). J. Mitchell Soc. 84, 462-466.

Burnham, K.P., Anderson, D.R., 2002. Model selection and multimodel inference: a practical information-theoretic approach. Ecol. Model. http://dx.doi.org/10.1016/j. ecolmodel.2003.11.004.

Casper, S.J., 1966. Monographie der gattung Pinguicula L. Sttutgart.

DeChaine, E.G., 2008. A bridge or a barrier? Beringia's influence on the distribution and diversity of tundra plants. Plant Ecol. Divers. 1, 197-207. http://dx.doi.org/10.1080/ 17550870802328660.

Downie, S.R., Katz-Downie, D.S., 1999. Phylogenetic analysis of chloroplast rps16 intron sequences reveals relationships within the woody southern African Apiaceae subfamily Apioideae. Can. J. Bot. 77, 1120-1135. http://dx.doi.org/10.1139/cjb-77-8 1120.

Doyle, J.J., Doyle, J.L., 1987. A rapid DNA isolation procedure for small quantities of fresh leaf tissue. Phytochem. Bull. 19, 11-15. http://dx.doi.org/10.2307/4119796.

Drummond, A.J., Suchard, M.A., Xie, D., Rambaut, A., 2012. Bayesian phylogenetics with BEAUti and the BEAST 1.7. Mol. Biol. Evol. 3-6. http://dx.doi.org/10.1093/molbev/ mss075.

Eriksson, O., Kainulainen, K., 2011. The evolutionary ecology of dust seeds. Perspect. Plant Ecol. Evol. Syst. 13, 73-87. http://dx.doi.org/10.1016/j.ppees.2011.02.002.

Ferrera, M.M., Fuentes, C.E.H., Castellanos, M.C., 1990. Análisis polínico de sedimentos marinos del occidente de la isla de la juventud (Cuba). Acta Bot. Hungar. 36, 145-161.

Felsenstein, J., 1985. Confidence limits on phylogenies: an approach using the bootstrap. Evolution (N. Y). http://dx.doi.org/10.2307/2408678.

Fischer, E., Porembski, S., Barthlott, W., 2000. Revision of the genus Genlisea (Lentibulariaceae) in Africa and Madagascar with notes on ecology and phytogeography. Nord. J. Bot. http://dx.doi.org/10.1111/j.1756-1051.2000.tb00746.x.

Fleischmann, A., 2012a. Monograph of the Genus Genlisea. Redfern Natural History Productions, Poole, Dorset, England.

Fleischmann, A., 2012b. The new Utricularia species described since Peter Taylor's monograph. Carniv. Plant Newsl. 41, 67-76.

Fleischmann, A., 2015. Taxonomic Utricularia news. Carniv. Plant Newsl. 44, 13-16.

Fleischmann, A., Michael, T.P., Rivadavia, F., Sousa, A., Wang, W., Temsch, E.M., Greilhuber, J., Müller, K.F., Heubl, G., 2014. Evolution of genome size and chromosome number in the carnivorous plant genus Genlisea (Lentibulariaceae), with a new estimate of the minimum genome size in angiosperms. Ann. Bot. 114, 1651-1663. http://dx.doi.org/10.1093/aob/mcu189.

Fleischmann, A., Rivadavia, F., Gonella, P.M., Heubl, G., 2011. A revision of Genlisea subgenus Tayloria (Lentibulariaceae). Phytotaxa 33, 1-40.

Font Quer, P., 1953. Diccionario De Botánica. Editorial Labor, S.A., Barcelona.

Geyer, C.J., 1991. Markov Chain Monte Carlo Maximum Likelihood. In: Comput. Sci. Stat. Proc. 23rd Symp. Interface, pp. 156-163.

Gouveia-Oliveira, R., Sackett, P.W., Pedersen, A.G., 2007. MaxAlign: maximizing usable data in an alignment. BMC Bioinform. 8, 312. http://dx.doi.org/10.1186/1471-21058-312.

Greilhuber, J., Borsch, T., Müller, K., Worberg, A., Porembski, S., Barthlott, W., 2006. Smallest angiosperm genomes found in Lentibulariaceae, with chromosomes of bacterial size. Plant Biol. 8, 770-777. http://dx.doi.org/10.1055/s-2006-924101.

Guisande, C., Camilo, C.G.-L., Andrade-Sossa, C., Duque, S.R., 2007. Bladderworts. Funct. Plant Sci. Biotechnol. 1, 58-68.

Hall, T., 1999. BioEdit: a user-friendly biological sequence alignment editor and analysis program for Windows 95/98/NT. Nucleic Acids Symp. Ser. doi:citeulike-articleid:691774

Hamilton, M.B., 1999. Primer Notes: four primer pairs for the amplification of chloroplast intergenic regions with intraspecific variation. Mol. Ecol. 8, 513-525. http://dx.doi. org/10.1046/j.1365-294X.1999.00510.x.

Heslop-Harrison, Y., 2004. Biological Flora of The British Isles (List Br. Vasc. (1958) n.441, 1-4) Pinguicula vulgaris L. J. Ecol. 1071-1118.

Huelsenbeck, J.P., Ronquist, F., 2001. MrBayes: Bayesian inference of phylogeny. Bioinformatics 17, 754-755. http://dx.doi.org/10.1093/bioinformatics/17.8.754.

Ibarra-Laclette, E., Albert, V.A., Pérez-Torres, C.A., Zamudio-Hernández, F., OrtegaEstrada, M.D.J., Herrera-Estrella, A., Herrera-Estrella, L., 2011. Transcriptomics and molecular evolutionary rate analysis of the bladderwort (Utricularia), a carnivorous plant with a minimal genome. BMC Plant Biol. 11, 101. http://dx.doi.org/10.1186/ 1471-2229-11-101.

Ibarra-Laclette, E., Lyons, E., Hernández-Guzmán, G., Pérez-Torres, C.A., CarreteroPaulet, L., Chang, T.-H., Lan, T., Welch, A.J., Juárez, M.J.A., Simpson, J., FernándezCortés, A., Arteaga-Vázquez, M., Góngora-Castillo, E., Acevedo-Hernández, G., Schuster, S.C., Himmelbauer, H., Minoche, A.E., Xu, S., Lynch, M., Oropeza-Aburto, A., Cervantes-Pérez, S.A., de Jesús Ortega-Estrada, M., Cervantes-Luevano, J.I., Michael, T.P., Mockler, T., Bryant, D., Herrera-Estrella, A., Albert, V.A., HerreraEstrella, L., 2013. Architecture and evolution of a minute plant genome. Nature 498, 94-98. http://dx.doi.org/10.1038/nature12132.

Jobson, R.W., 2012. Utricularia corneliana R.W.Jobson (Lentibulariaceae), a new species from North Kennedy district of Queensland. Austrobaileya 8, 601-607.

Jobson, R.W., Albert, V.A., 2002. Molecular rates parallel diversification contrasts between carnivorous plant sister lineages. Cladistics 18, 127-136. http://dx.doi.org/ 10.1006/clad.2001.0187.

Jobson, R.W., Playford, J., Cameron, K.M., Albert, V.A., 2003. Molecular Phylogenetics of Lentibulariaceae Inferred from Plastid rps16 Intron and trnL-F DNA Sequences: implications for Character Evolution and Biogeography. Syst. Bot. 28, 157-171. http:// dx.doi.org/10.2307/3093945.

Juniper, B., Robins, R., Joel, D., 1989. The Carnivorous Plants. Academic Press, Oxford.

Kameyama, Y., Toyama, M., Ohara, M., 2005. Hybrid origins and F1 dominance in the free-floating, sterile bladderwort, Utricularia australis f. australis (Lentibulariaceae). Am. J. Bot. 92, 469-476. http://dx.doi.org/10.3732/ajb.92.3.469.

Katoh, K., Standley, D.M., 2013. MAFFT Multiple Sequence Alignment Software Version 7: Improvements in Performance and Usability Article Fast Track 30, pp. 772-780. http://dx.doi.org/10.1093/molbev/mst010.

Komiya, S., 1973. New subdivision of the Lentibulariaceae. J. Jpn. Bot. 48, 147-153.

Kress, W.J., Erickson, D.L., Jones, F.A., Swenson, N.G., Perez, R., Sanjur, O., Bermingham, E., 2009. Plant DNA barcodes and a community phylogeny of a tropical forest dynamics plot in Panama. Proc. Natl. Acad. Sci. U. S. A. 106, 18621-18626. http://dx. doi.org/10.1073/pnas.0909820106.

Król, E., Płachno, B.J., Adamec, L., Stolarz, M., Dziubińska, H., Trebacz, K., 2012. Quite a few reasons for calling carnivores "the most wonderful plants in the world" Ann. Bot. 109, 47-64. http://dx.doi.org/10.1093/aob/mcr249.

Les, D.H., Crawford, D.J., Kimball, R.T., Moody, M.L., Landolt, E., 2003. Biogeography of discontinuously distributed hydrophytes: a molecular appraisal of intercontinental disjunctions. Int. J. Plant Sci. 164, 917-932. http://dx.doi.org/10.1086/378650.

Levin, R.A., Wagner, W.L., Hoch, P.C., Nepokroeff, M., Pires, J.C., Zimmer, E.A., Sytsma, K.J., 2003. Family-level relationships of Onagraceae based on chloroplast $r b c L$ and $n d h F$ data. Am. J. Bot. 90, 107-115. http://dx.doi.org/10.3732/ajb.90.1.107.

Li, D.-Z., Gao, L.-M., Li, H.-T., Wang, H., Ge, X.-J., Liu, J.-Q., Chen, Z.-D., Zhou, S.-L., Chen, S.-L., Yang, J.-B., Fu, C.-X., Zeng, C.-X., Yan, H.-F., Zhu, Y.-J., Sun, Y.-S., Chen, S.-Y., Zhao, L., Wang, K., Yang, T., Duan, G.-W., 2011. Comparative analysis of a large dataset indicates that internal transcribed spacer (ITS) should be incorporated into the core barcode for seed plants. Proc. Natl. Acad. Sci. U. S. A. 108 19641-19646. http://dx.doi.org/10.1073/pnas.1104551108.

Lloyd, F.E., 1935. Utricularia. Biol. Rev. 10, 72-110.

Lobreau-Callen, D., Jérémie, J., Suarez-Cervera, M., 1999. Morphologie et ultrastructure du pollen dans le genre Utricularia L. (Lentibulariaceae). Can. J. Bot. 77, 744-767. http://dx.doi.org/10.1139/cjb-77-5-744.

Lodhi, M.A., Ye, G.-N., Weeden, N.F., Reisch, B.I., 1994. A simple and efficient method for DNA extraction from grapevine cultivars and Vitis species. Plant Mol. Biol. Report 12 6-13. http://dx.doi.org/10.1007/BF02668658.

Maddison, W.P., Maddison, D.R., 2010. Mesquite: A Modular System for Evolutionary Analysis. Version 2.73, http://mesquiteproject.org.

McPherson, S., 2010. Carnivorous Plants and Their Habitats. Redfern Natural History Productions, Poole, Dorset, England.

Menezes, C.G., Gasparino, E.C., Baleeiro, P.C., Miranda, V.F.O., 2014. Seed morphology of bladderworts: a survey on Utricularia sect. Foliosa and sect. Psyllosperma (Lentibulariaceae) with taxonomic implications. Phytotaxa 167, 173-182.

Miller, M.A., Pfeiffer, W., Schwartz, T., 2010. Creating the CIPRES Science Gateway for inference of large phylogenetic trees. In: 2010 Gateway Computing Environments Workshop, GCE 2010. http://dx.doi.org/10.1109/GCE.2010.5676129.

Miranda, V.F.O., Martins, V.G., Furlan, A., Bacci Jr, M., 2010. Plant or fungal sequences? An alternative optimized PCR protocol to avoid ITS (nrDNA) misamplification. Braz. Arch. Biol. Technol. 53, 141-152.

Muller, J., 1984. Significance of Fossil Pollen for Angiosperm History. Ann. Missouri Bot. Gard. 71, 419-443. http://dx.doi.org/10.2307/2399033.

Müller, K., Borsch, T., 2005. Phylogenetics of Utricularia (Lentibulariaceae) and molecular evolution of the trnK intron in a lineage with high substitutional rates. Plant Syst. Evol. 250, 39-67. http://dx.doi.org/10.1007/s00606-004-0224-1.

Müller, K., Borsch, T., Legendre, L., Porembski, S., Theisen, I., Barthlott, W., 2004. Evolution of Carnivory in Lentibulariaceae and the Lamiales. Plant Biol. 1875. http:// dx.doi.org/10.1055/s-2004-817909.

Müller, K.F., Borsch, T., Legendre, L., Porembski, S., Barthlott, W., 2006. Recent progres in understanding the evolution of carnivorous Lentibulariaceae (Lamiales). Plant Biol. (Stuttg) 8, 748-757. http://dx.doi.org/10.1055/s-2006-924706.

O'Dea, A., Lessios, H.A., Coates, A.G., Eytan, R.I., Restrepo-Moreno, S.A., Cione, A.L., Collins, L.S., de Queiroz, A., Farris, D.W., Norris, R.D., Stallard, R.F., Woodburne, M.O., Aguilera, O., Aubry, M.-P., Berggren, W.A., Budd, A.F., Cozzuol, M.A., Coppard, S.E., Duque-Caro, H., Finnegan, S., Gasparini, G.M., Grossman, E.L., Johnson, K.G., Keigwin, L.D., Knowlton, N., Leigh, E.G., Leonard-Pingel, J.S., Marko, P.B., Pyenson, N.D., Rachello-Dolmen, P.G., Soibelzon, E., Soibelzon, L., Todd, J.A. Vermeij, G.J., Jackson, J.B.C., 2016. Formation of the Isthmus of Panama. Sci. Adv. 2, e1600883. http://dx.doi.org/10.1126/sciadv.1600883.

Palmer, J.D., Jansen, R.K., Michaels, H.J., Chase, M.W., Manhart, J.R., 1988. Chloroplast DNA variation and plant phylogeny. Ann. Missouri Bot. Gard. 75, 1180-1206. http:// dx.doi.org/10.2307/2399279.

Płachno, B.J., Adamec, L., Kozieradzka-Kiszkurno, M., Swiątek, P., Kamińska, I., 2014 Cytochemical and ultrastructural aspects of aquatic carnivorous plant turions. Protoplasma 7-12. http://dx.doi.org/10.1007/s00709-014-0646-8.

Płachno, B.J., Clivati, D., Miranda, V.F.O., Świątek, P., 2009. Are there seed pedestals in Lentibulariaceae. Acta Biol. Cracoviensia Ser. Bot. 51, 115-118.

Płachno, B.J., Kozieradzka-Kiszkurno, M., Swiątek, P., Darnowski, D.W., 2008. Prey attraction in carnivorous Genlisea (Lentibulariaceae). Acta Biol. Cracoviensia Ser. Bot. $50,87-94$.

Płachno, B.J., Stpiczyńska, M., Davies, K.L., Świątek, P., Miranda, V.F.O., 2017. Floral ultrastructure of two Brazilian aquatic-epiphytic bladderworts: Utricularia cornigera Studnička and U. nelumbifolia Gardner (Lentibulariaceae). Protoplasma 254, 
353-366. http://dx.doi.org/10.1007/s00709-016-0956-0.

Płachno, B.J., Świątek, P., 2010. Unusual embryo structure in viviparous Utricularia nelumbiulfolia, with remarks on embryo evolution in genus Utricularia. Protoplasma 239 (1), 69-80. http://dx.doi.org/10.1007/s00709-009-0084-1.

Poppinga, S., Weisskopf, C., Westermeier, A.S., Masselter, T., Speck, T., 2015. Fastest predators in plant kingdom: Functional morphology and biomechanics of suction traps found in the largest genus of carnivorous plants. AoB Plants plv140. http://dx. doi.org/10.1093/aobpla/plv140.

Raven, J.A., 2013. Rubisco: Still the most abundant protein of Earth? New Phytol. 198, 1-3. http://dx.doi.org/10.1111/nph.12197.

Reut, M.S., Jobson, R.W., 2010. A phylogenetic study of subgenus Polypompholyx: a parallel radiation of Utricularia (Lentibulariaceae) throughout Australasia. Aust. Syst. Bot. 23, 152-161.

Rodrigues, F.G., Marulanda, N.F., Silva, S.R., Płachno, B.J., Adamec, L., Miranda, V.F.O., 2017. Phylogeny of the 'orchid-like' bladderworts (gen. Utricularia sect. Orchidioides and Iperua: Lentibulariaceae) with remarks on the stolon-tuber system. Ann. Bot. http://dx.doi.org/10.1093/aob/mcx056.

Robinson, D.F., 1971. Comparing labeled trees with valency three. J Comb Theory B. 11, 105-119.

Roccia, A., Gluch, O., Lampard, S., Robinson, A., Fleischmann, A., McPherson, S., Legendre, L., Partrat, E., Temple, P., 2016. Pinguicula of the Temperate North. Redfern Natural Histoy Productions, Dorset.

Ronquist, F., Teslenko, M., van der Mark, P., Ayres, D.L., Darling, A., Höhna, S., Larget, B., Liu, L., Suchard, M.A., Huelsenbeck, J.P., 2012. MrBayes 3.2: efficient Bayesian phylogenetic inference and model choice across a large model space. Syst. Biol. 61, 539-542. http://dx.doi.org/10.1093/sysbio/sys029.

Rutishauser, R., 2016. Evolution of unusual morphologies in Lentibulariaceae (bladderworts and allies) and Podostemaceae (river-weeds): a pictorial report at the interface of developmental biology and morphological diversification. Ann. Bot. 117, 811-832. http://dx.doi.org/10.1093/aob/mcv172.

Rutishauser, R., 1999. Polymerous leaf whorls in vascular plants: developmental morphology and fuzziness of organ identities. Int. J. Plant Sci. 160, S81-S103.

Rutishauser, R., Isler, B., 2001. Developmental genetics and morphological evolution of flowering plants, especially Bladderworts (Utricularia): Fuzzy Arberian morphology complements classical morphology. Ann. Bot. 88, 1173-1202. http://dx.doi.org/10. 1006/anbo.2001.1498.

Santorum, J.M., Darriba, D., Taboada, G.L., Posada, D., 2014. Jmodeltest. Org: selection of nucleotide substitution models on the cloud. Bioinformatics 1-2. http://dx.doi. org/10.1093/bioinformatics/btu032.

Shivakumar, V.S., Appelhans, M.S., Johnson, G., Carlsen, M., Zimmer, E.A., 2016. Analysis of whole chloroplast genomes from the genera of the Clauseneae, the Curry tribe (Rutaceae, Citrus family). Mol. Phylogenet. Evol. http://dx.doi.org/10.1016/j. ympev.2016.12.015.

Silva, S.R., Diaz, Y.C.A., Penha, H.A., Pinheiro, D.G., Fernandes, C., Miranda, V.F.O., Michael, T.P., Varani, A.M., 2016. The chloroplast genome of Utricularia reniformis sheds light on the evolution of the ndh gene complex of terrestrial carnivorous plants from the Lentibulariaceae family. PLoS ONE. http://dx.doi.org/10.1371/journal. pone. 0165176.

Sirová, D., Adamec, L., Vrba, J., 2003. Enzymatic activities in traps of four aquatic species of the carnivorous genus Utricularia. New Phytol. 159, 669-675. http://dx.doi.org/ 10.1046/j.1469-8137.2003.00834.x.

Sirová, D., Borovec, J., Černá, B., Rejmánková, E., Adamec, L., Vrba, J., 2009. Microbial community development in the traps of aquatic Utricularia species. Aquat. Bot. 90, 129-136. http://dx.doi.org/10.1016/j.aquabot.2008.07.007.

Stamatakis, A., Hoover, P., Rougemont, J., 2008. A rapid bootstrap algorithm for the RAxML Web servers. Syst. Biol. 57, 758-771. http://dx.doi.org/10.1080/ 10635150802429642.

Steenis, C.G.G.J. Van, 1978. Rheophytes in South Africa. Bothalia 12, 543-546.

Stöver, B.C., Müller, K.F., 2010. Treegraph2: combining and visualizing evidence from different phylogenetic analyses. BMC Bioinform. 11. http://dx.doi.org/10.1186/ 1471-2105-11-7.

Swofford, D.L., 2002. PAUP* Phylogenetic Analysis Using Parsimony* (and other methods). version 4.0. Sinauer Assoc. Sunderland, Massachusetts.

Taylor, P., 1989. Genus Utricularia: A Taxonomic Monograph, first ed. Royal Botanic Gardens, Kew, London.

Taylor, P., 1986. New Taxa in Utricularia (Lentibulariaceae). Kew Bull. 41, 1-18. http:// dx.doi.org/10.2307/4103020.

Taylor, P., 1977. Lentibulariaceae. Flora Malesiana I, vol. 8, The Hague, pp. 275-300.

Trevisan, R., Moço, M.C.C., 2011. Ocorrência de Utricularia olivacea C.Wright ex Griseb. (Lentibulariaceae) no Rio Grande do Sul, Brasil. R. Bras. Bioci. 9, 249-251.

Valdés, C.M.P., 2008. El género Utricularia (Lentibulariaceae) en las Antillas Mayores. Revista del Jardín Botánico Nacional 29, 11-19.

Van Geel, B., Protopopov, A., Bull, I., Duijm, E., Gill, F., Lammers, Y., Nieman, A., Rudaya, N., Trofimova, S., Tikhonov, A.N., Vos, R., Zhilich, S., Gravendeel, B., 2014. Multiproxy diet analysis of the last meal of an early Holocene Yakutian bison. J. Quat. Sci. 29, 261-268. http://dx.doi.org/10.1002/jqs.2698.

Veleba, A., Bureš, P., Adamec, L., Šmarda, P., Lipnerová, I., Horová, L., 2014. Genome size and genomic GC content evolution in the miniature genome-sized family. New Phytol. 203, 22-28.

Vincent, O., Weißkopf, C., Poppinga, S., Masselter, T., Speck, T., Joyeux, M., Quilliet, C., Marmottant, P., 2011. Ultra-fast underwater suction traps. Proc. R. Soc. B 278, 2909-2914. http://dx.doi.org/10.1098/rspb.2010.2292.

Westermeier, A.S., Fleischmann, A., Müller, K., Schäferhoff, B., Rubach, C., Speck, T., Poppinga, S., 2017. Trap diversity and character evolution in carnivorous bladderworts (Utricularia, Lentibulariaceae). Sci. Rep. 7, 12052. http://dx.doi.org/10.1038/ s41598-017-12324-4.

White, T.J., Bruns, S., Lee, S., Taylor, J., 1990. Amplification and Direct Sequencing of Fungal Ribosomal RNA Genes for Phylogenetics. PCR Protoc. A Guid. to Methods Appl. doi:citeulike-article-id:671166.

Yu, Y., Harris, A.J., Blair, C., He, X., 2015. RASP (Reconstruct Ancestral State in Phylogenies): a tool for historical biogeography. Mol. Phylogenet. Evol. 87, 46-49. http://dx.doi.org/10.1016/j.ympev.2015.03.008. 